\title{
Crisis mística, educación y juventud La formación del perfil moral del periodismo en la revista Política, 1960-1967
}

Mystic crisis, education and youth

The formation of the journalism's moral profile in the Política review, 1960-1967

Juan Carlos Sánchez Sierra

Resumen

Palabras clave

Abstract

Keywords
Becario posdoctoral del Centro de Investigaciones Interdisciplinarias en Ciencias y Humanidades de la Universidad Nacional Autónoma de México, actualmente adelanta la investigación “Imágenes y representaciones de la masculinidad en la cultura popular de izquierdas en México, 1960-1980". Doctor en Pensamiento Social y Político por la Universidad Tecnológica de Virginia, es coordinador del libro Juventud, Nación y movilización política en América Latina, 1960-2010, Santiago de Chile, RIL, en prensa. Su dirección de correo electrónico es: jcarlosssierra@gmail.com.

En este artículo se explora la crisis de la mística nacionalista como un proceso que transformó las imágenes de "lo revolucionario" durante la década de 1960. La erosión de esos símbolos, la educación juvenil y la cultura popular constituyeron temas centrales en el periodismo de la izquierda. A través de un examen de Política (19601967), se busca identificar la manera como se configuró un perfil heroico de la izquierda en la década de 1960, a través de un examen del contexto periodístico e intelectual en el que la crisis de la Revolución mexicana fue examinada por periodistas e intelectuales.

Periodismo, izquierda, heroísmo, mística, juventud, educación.

In this article the crisis of the nationalist mysticism is explored as a process that transformed the images of "the revolutionary" during the 1960 decade. The erosion of these symbols, youth education and popular culture, constituted central topics in left journalism. Through an inspection of Política (1960-1967), this article intends to identify how a heroic profile of the left was created in the 1960 decade, through an exam of the journalistic and intellectual context in which the Mexican Revolution crisis was analyzed by journalists and intellectuals.

Journalism, left, heroism, mysticism, youth, education.

Recibido/Received 31 de agosto de 2012

Aprobado/Approved 


\title{
Crisis mística, educación y juventud
}

\author{
La formación del perfil moral del periodismo en la revista Política, \\ 1960-1967
}

Juan Carlos Sánchez Sierra

Ha engordado. Su cuello, sus muñecas, sus dedos son el asiento de lujosas joyas. Usa perfumes caros y pieles de alto precio. Come en lujosos restaurantes, baila en el Country Club, viaja por Europa, educa a sus hijos en el extranjero y es aficionada a las comidas pantagruélicas y a pagar por una copa lo que no gana un campesino en una semana de trabajo [...]. Pero la desenfrenada e iconoclasta muchacha que bailó en los campamentos, que tragó el polvo de las duras jornadas, que curó las heridas y mitigó la sed de los guerreros en días de victorias y derrotas, hace rato que se cortó las trenzas desafiantes, que se pulió las uñas y se maquilló el rostro para bailar, en danza interminable, con don Porfirio. ${ }^{1}$

\section{Introducción}

Extraviada del rumbo que se le asignó en 1917, desde finales de la década de 1950 la Revolución mexicana fue vista por la prensa de izquierda como un despojo irreconocible, distante del esplendor de sus días de gloria. ${ }^{2}$

1 José Santos Valdez, “Bailando con don Porfirio”, Política, México, D. F., 15 de marzo de 1962, p. 28.

2 El periodista Santos Valdez no estaba lejos de la idea que se hacían otros de sus compañeros en la revista Política, fundada y dirigida por Manuel Marcué Pardiñas desde 1960 y que circuló hasta 1967. Pero esta no sería la única asociación de la revolución con una imagen de mujer, pues además de pintoreteada, también se la dibujó cargada de otras vejaciones y se la tildó de prostituta. Fue una época de contrastes, pues mientras se exponían las lacras de la revolución de 1910-1917, se exaltaba la Revolución cubana como una epopeya señera que despertó el valor redentor de héroes revolucionarios innovadores, viriles, hombres nuevos promotores de un campo de la lucha social, que más bien parecía la alegoría de un territorio propicio para la interacción homosocial vedado para las mujeres. El problema estaba en que 
Inmune a cualquier riesgo de ser condenado como apátrida, José Santos Valdez publicó en 1962 una columna titulada Bailando con don Porfirio en la que describió de forma gráfica y descarnada la imagen que tenía de la Revolución mexicana. Aunque no fue el único ni el primero, su juicio fue lanzado contra el gobierno y el periodismo. El primero, a su juicio, estaba cargado de hombres que -aunque llevaban en sus hombros el peso histórico y la autoridad moral de la revolución- la dilapidaban, hombres del gobierno entre los que "pocos, muy pocos hombres se salvan de los que ahora tienen el poder. Pocos muy pocos de los que forman el monopolio revolucionario merecen nuestro respeto". El segundo, según Santos Valdez, era una profesión en decadencia, practicada por personas que "con toda justicia hacen desde el periodismo nacional" una idea falsificada de la Revolución mexicana. Los periodistas de la llamada "Gran Prensa", así como la revolución a la que apelaban, eran objeto del repudio de la izquierda mexicana, pues cobijados en la colusión con el régimen, impulsaban la educación y la cultura popular que mantenía a la sociedad enajenada en los delirios del "American way of life".

La década de 1960 tuvo como característica la creciente exaltación del oficio periodístico de izquierdas como un arquetipo moral, un aspecto que fomentó la visión heroica de periodistas e intelectuales involucrados en el activismo de oposición. Política (1960-1967) se erigió como la síntesis de esos valores morales, y reunió algunos de los principales exponentes del oficio. En este artículo se examina el perfil moral del periodismo, a la luz de temas tratados en la revista relacionados con la crisis política de México, y la esperanza depositada en la juventud y la educación como su solución. Aquí se explora la crisis de la mística nacionalista como un proceso que transformó las imágenes de "lo revolucionario" en el México de la década de 1960. Aunque no se analizan las representaciones de género en el imaginario político de la izquierda mexicana, el objetivo es allanar el camino para ir vislumbrando en el largo plazo los perfiles de masculinidad revolucionaria. ${ }^{3}$ En su lugar, se busca identificar la manera como se confi-

la idea de la revolución, femenina, violada, prostituida, se quedaría en la mentalidad de la izquierda mexicana, mientras la exaltación de sus hacedores se mantendría como un terreno masculino hasta más allá de la represión al movimiento estudiantil de 1968.

3 Es notable que la imagen de la revolución, prostituida y humillada, era una conceptualización feminizada análoga a la también vilipendiada "nación" y la "patria". Este es un aspecto que 
guró un perfil moral de la izquierda en la década de 1960, a través de un examen del contexto periodístico e intelectual en el que la crisis de la Revolución mexicana fue examinada por periodistas e intelectuales.

Este problema de investigación ya ha sido abordado por dos investigadoras norteamericanas, que de algún modo inspiraron esta investigación con su análisis de los perfiles heroicos masculinos formados durante y después del movimiento popular y estudiantil de 1968.4 Sin embargo, la subjetividad revolucionaria que emergió de la mano del periodismo practicado en Política fue importante porque marcó el preludio contestatario de una generación de la izquierda que creció durante una década marcada por episodios de represión, para luego ser atropellada en la masacre de Tlatelolco. Los estudios de los perfiles heroicos de la izquierda mexicana contemporánea han recibido menor atención en comparación con aquellos de la época de la independencia, el siglo XIX y la Revolución. Autores que estudian la educación, la cultura popular y los rituales cargados de simbolismo en la vida política mexicana han subrayado la necesidad de trabajos que amplíen esta frontera de conocimiento. ${ }^{5}$

arroja luz sobre la correlación en los discursos morales del periodismo -oficialista y de oposición- entre la decadencia y las marcas de violencia que exhibía México en su crisis de las décadas de 1960 y 1970. Esta investigación forma parte del proyecto “Liderazgo, cultura política y prácticas de moralidad: la izquierda en México, 1960-1980”, en el que los hallazgos han señalado la problemática de género como una de las variables centrales de análisis. Aunque aquí no se aborda este aspecto, en general se busca establecer la dinámica del periodismo político y cultural de izquierdas como insumo para una investigación sobre la particular forma en que se asimilaron los discursos y prácticas asociadas con el ideal revolucionario del hombre nuevo. Es importante aclarar, que Política no fue la única publicación que tuvo esta tendencia en su línea editorial y las prácticas periodísticas internas. En otros casos estudiados en esta investigación como el de México en la Cultura, ¿Por Qué?, Sucesos, Siempre!, La Cultura en México y Estrategia, entre muchas otras, ha permitido detectar que tanto el periodismo heroico de izquierdas como la subjetividad revolucionaria de la época eran campos homosociales de disputa donde predominaron relaciones disociadas del discurso editorial que sostenía la necesidad de incluir a la mujer en la tarea de construir un cambio en la estructura política y social de México.

4 Deborah Cohen, Lessie Jo Frazier, “México 68: hacia una definición del espacio del movimiento. La masculinidad heroica en la cárcel y las ‘mujeres' en las calles”, Estudios Sociológicos, v. 22, n. 3, 2004, p. 591-623; Deborah Cohen, Lessie Jo Frazier, “'No sólo cocinabamos...': historia inédita de la otra mitad del 68”, en Ilán Semo, La transición interrumpida: México 1968-1988, México, Universidad Iberoamericana/Nueva Imagen, 1993.

5 Cfr. William H. Beezley et al., Rituals of rule, rituals of resistance: public celebrations and popular culture in Mexico, Wilmington, SR Books, 1994; Mary Vaughan, La política cultural 
En este artículo exploro la revista Política (1960-1967), en busca de los temas centrales con los que se debatieron problemáticas relacionadas con la autoridad moral del periodismo opositor al régimen político. Estos temas dieron contorno a la figura del periodista heroico, a la vez que legitimaron la lucha de la izquierda en México. En la investigación se encontró que la decadencia de los anclajes simbólicos del régimen político sirvió al periodismo de la izquierda para que hiciera pública y manifiesta la saciedad de amplios sectores sociales con las prácticas políticas que perpetuaban al PRI en el poder. La erosión de esos símbolos, la educación juvenil y la cultura popular constituyeron temas centrales en el periodismo de la izquierda aglomerado alrededor de Política.

En la primera parte del artículo, se aborda la crisis de la mística nacionalista mexicana y el papel que jugaba Política como vanguardia del periodismo de la oposición al régimen. Buena parte del esfuerzo analítico de la realidad mexicana en la revista se orientó a desacralizar el sistema político, un proceso llevado a cabo por medio de la denuncia de las prácticas inmorales que impedían el despertar democrático en el país. En la revista se fue acondicionando el debate sobre la "autoridad moral" del régimen, y el papel que desempeñaban los actores sociales en la restauración de la Revolución mexicana hacia su camino inicial. Estos temas influyeron en el delineamiento de un perfil heroico revolucionario que coincidía con las actividades de los columnistas de la publicación.

En la segunda parte del artículo, se observa cómo el carácter moralizante del discurso de la izquierda congregada en Política tenía como objeto concientizar a la sociedad, y fue allí donde el papel del periodista se erigió como un arquetipo del compromiso político, subrayado por el peligro y sacrificios que implicaba el desempeño de su profesión. Desde 1962 ese perfil se bosquejó a través de columnas y editoriales que trataron el tema de la educación pública, la juventud y la cultura popular mexicana. En esta parte se examina la forma como el debate de la educación y los libros de texto -ocurrido ente 1961 y 1963- reveló problemas en la calidad educativa y los fundamentos pedagógicos que orientaban el sistema escolar

en la Revolución: maestros, campesinos y escuelas en México, 1930-1940, México, Fondo de Cultura Económica, 2001; Joseph Gilbert et al., Fragments of a golden age: the politics of culture in Mexico since 1940, Durham, Duke University Press, 2001. 
mexicano. La brecha educativa, en términos de calidad, impedía un examen crítico de los anclajes místicos del civismo nacionalista, lo que le abría paso a elementos de la cultura popular -como el periodismo de izquierdaspara activar un discurso moral alternativo. Las columnas publicadas en Política fueron el mejor ejemplo hasta 1967. El análisis del perfil moral del periodismo permite comprender la configuración del imaginario político de la izquierda mexicana en la década de 1960, en el contexto del despertar de nuevos actores involucrados en debates públicos pese a que desempeñaban un papel marginalizado por discursos editoriales paternalistas y condescendientes.

\section{De la crisis de la Revolución al periodismo heroico}

Desde el momento de su lanzamiento, Política denunció el desmedro de la mística nacional, y el profundo problema que representaba el uso y abuso de la noción de revolución. Fue seis meses después de su aparición, cuando ya contaba con una amplia fanaticada entre la izquierda urbana y las zonas rurales donde llegaba la revista, cuando la oportunidad de poner el dedo en la llaga llegó. Para el cuerpo editorial de la revista, la mística nacionalista y sus anclajes en el folclore popular que eran celebrados con furor y puntualidad cada año entre septiembre y noviembre, habían perdido asidero moral en la población. Este señalamiento serviría para que la izquierda sentara su posición en el país, pues desde la aparición del primer número en mayo de 1960, era claro que la orientación principal de la publicación era promover una reanimación de los valores y preceptos de la Revolución mexicana a la luz de la experiencia cubana, que resultaba ser un parteaguas político para una generación sumida en el desencanto de un proceso social desviado de sus metas proyectadas. ${ }^{6}$ Alonso Aguilar, periodista cercano al director Manuel Marcué Pardiñas desde la década de 1950 durante las aventuras editoriales en la revista Problemas Agrícolas e Industriales de México (PAIM), ${ }^{7}$ señalaba la forma como el uso de los medios masivos de comunicación

6 Juan Rafael Reynaga Mejía, La Revolución cubana a través de la revista Política en México: construcción imaginaria de un discurso para América Latina, tesis de licenciatura en Estudios Latinoamericanos, México, Universidad Nacional Autónoma de México, 2005.

7 Cfr. José Rivera Castro, "Balance histórico de la revista Problemas Agrícolas e Industriales de México", Tiempo y Escritura, Universidad Autónoma Metropolitana, 1 (2004) [documento 
servía para "propagar la celebración de la Revolución en sus 50 años", señalando el nivel al que había llegado la manipulación del lenguaje, en tanto la burguesía que controlaba los medios de prensa, radio y televisión hacía un uso "consciente de la conveniencia y aun de la necesidad de hablar en revolucionario". ${ }^{8}$ En efecto "lo revolucionario" se había desvanecido hasta llegar a ser un discurso vacío pero legitimador, y la Revolución cubana representaba una tabla de fe para cambiar tal situación. A estas aseveraciones de Alonso Aguilar se sumaron las de José Arenas, en las que señaló que la demagogia mancillaba los ideales de la revolución, pues aunque se suponía que convocaba "energía humana, talento" y vínculos de "confianza de unos en otros por una empresa común”, los valores que para 1960 fomentaba habían sido trastornados y la devoción por la justicia social estaba ya rota. Este columnista también apuntó algunos de los limitantes para el florecimiento de esos valores colectivos como la corrupción, el amiguismo y el exceso de poder presidencial, además de una erosión de los anclajes simbólicos: "el balance de la revolución arroja un saldo en rojo de penuria moral", debatida entre sus "contradicciones y sus falsos horizontes de papel escrito, y su creación continua de una realidad ficticia, sus mitos, sus iconos, su magia". ${ }^{9}$ La crisis moral a la que arrastró la desviación de la Revolución mexicana iba en detrimento de valores colectivos y afectaba entonces a los hombres que la impulsaban desde el gobierno.

Se trataba de un reclamo que la izquierda hizo sentir cada año promediando agosto, y hasta pasado el mes de diciembre. El tono de esta reverberación editorial se agudizaba cuando había elecciones, o en el mes de noviembre cuando se exaltaba la mexicanidad en el día de muertos y el aniversario de la Revolución. Cuando Benjamín Carrión denunció que los "arsenales místicos”, que eran comunes a los nacionalismos de América Latina, servían de lustre para la demagogia del cambio social, Enrique González Pedrero - catedrático de la Escuela de Ciencias Políticas de la UNAM y promotor de publicaciones sobre economía en el Fondo de Cultura Económica, donde

en línea en formato html: http://www.azc.uam.mx/publicaciones/tye/tye16/art_hist_01. html, consultado el 31 de agosto de 2012.

8 Alonso Aguilar, “Urge tomar otro camino", Política, México, D. F., 15 de noviembre de 1960, p. 38.

9 José Arenas, “La revolución y sus abstracciones”, Política, México, D. F., 15 de noviembre de 1960, p. 71. 
estrechó relaciones con Manuel Marcué Pardiñas y su revista PAIM- ya había titulado una de sus columnas quincenales "Una sinfonía revolucionaria inconclusa" ${ }^{10}$ Allí repudió al senador Manuel Moreno Sánchez, cuando éste alegó en plenas ceremonias de la liturgia del régimen que "o se realiza la Revolución o se hace una nueva", ante su incapacidad para devolver la Revolución a su cauce originario. ${ }^{11}$ Se trataba de uno de los senadores más poderosos y representativos del "carro completo" legislativo y su comentario cayó mal en un contexto de incapacidad de los periodistas para hacer mella en la actitud testaruda del gobierno por promover una reforma política de fondo, en lugar de perpetuarse gracias a la reanimación de un imaginario de legitimidad ampliamente cuestionado por la izquierda.

En los años 1960, la crisis de la izquierda se debía en parte a la consideración -guiada por los principales partidos que aglutinaban a sus militantes- según la cual la desviación de la Revolución mexicana ocurrida desde los años 1940 había pervertido la burguesía nacional, mientras favorecía liderazgos contraproducentes para el sistema político. De allí que los militantes de la izquierda consideraran que, para regresar la Revolución a su camino inicial, sería necesario el cambio de esos líderes y de las prácticas que lograron establecer como normal en la mentalidad pública el hecho de tener en el aparato estatal una maquinaria corrupta. Si algo lograron las primeras décadas de gobiernos posrevolucionarios fue implantar una percepción de "lo político" como algo ajeno, distanciado de la esfera social por la potencia mística de su legado; igualmente el legado político de la revolución había sido expropiado por los mismos sectores que dominaban los mecanismos del ritual revolucionario. ${ }^{12}$

Parte de la responsabilidad en el establecimiento del poder político como un feudo vedado para el pueblo recaía en el ejercicio del periodismo como profesión. Uno de los temas predominantes en los debates edi-

10 Benjamín Carrión, “Una sinfonía revolucionaria inconclusa”, Política, México, D. F., 15 de enero de 1962, p. 4.

11 Enrique González Pedrero, “Una sinfonía revolucionaria inconclusa”, Política, México, D. F., 1 de diciembre de 1961, p. 32.

12 Cfr. Daniel Cosío Villegas, La crisis de México, México, Clío, 1997; Daniel Cosío Villegas, El sistema político mexicano: las posibilidades de cambio, México, Joaquín Mortiz, 1976; Barry Carr, La izquierda mexicana a través del siglo XX, México, Era, 1996; Roderic Camp, Líderes políticos de México, su educación y reclutamiento, México, Fondo de Cultura Económica, 1983. 
toriales de finales de la década de 1950 y comienzos de 1960 era el de la libertad de prensa. A este tópico se sumaban graves cuestionamientos sobre el proceder de periodistas profesionales adictos al poder, quienes constituyeron uno de los principales aditivos en el debate intelectual mexicano que se filtraba a la sociedad por la vía de la prensa. Política nació y se enfrentó al degradado valor del periodismo, con la intención de restablecer los parámetros legales de la Revolución mexicana, impulsados en buena medida por el aire fresco proveniente de Cuba como ejemplo moral y político de un auténtico proceso revolucionario. Esto explica en parte la importancia que el periodismo tenía en la afirmación política del país, pues a la vez que difundía la información que mantendría atenta del devenir político a la ciudadanía, Política también asumió la responsabilidad de promover un umbral crítico para que la sociedad supervisara al régimen, y así lograr que éste modificara el rumbo que años atrás había equivocado. ${ }^{13}$

A pesar de esta tarea de promover prácticas democráticas a través de la elevación del nivel de conciencia social de la población, el periodismo de oposición subrayaba la forma como el sistema político se había infestado de vicios que en un marco moral se alejaban de su compromiso ético y social. Regresando al análisis del artículo antes citado, Enrique González Pedrero protestaba contra la hipocresía de los funcionarios ataviados de dignidad histórica y autoridad moral durante los días de guardar, pues

13 Pese a las inconsistencias ideológicas que marcaron su línea editorial, Política fue vista como el principal medio escrito de oposición en los años 1960, por lo que fue constantemente hostigada por el régimen a través de mecanismos como la discontinuidad en el suministro de papel que PIPSA le asignaba, la instigación a sus empleados para entrar en paro, los cobros del IMSS y acreedores privados en momentos de pobreza franciscana, o la mezquindad en los subsidios con los que podía subsistir. Cfr. Jacinto Rodríguez Munguía, La otra guerra secreta: los archivos prohibidos de la prensa y el poder, México, Random House Mondadori, 2007. Esta es una de las obras más significativas donde se menciona la revista, y que permite conocer la forma como en algunas oportunidades Política se sostuvo económicamente con la ayuda de personalidades del régimen como Alfonso Corona del Rosal, o de la crisis que trajo para la revista las fricciones entre Manuel Marcué y David Alfaro Siqueiros en sus últimos años, así como una sucinta explicación de los factores que llevaron a su cierre en diciembre de 1967 . Se trata de un trabajo en el que se contrastan las percepciones que la izquierda tenía de las publicaciones mexicanas, con la documentación de los organismos de seguridad del estado merced a la disponibilidad de dichos documentos que hoy reposan en el Archivo General de la Nación. Agradezco a uno de los dictaminadores de este artículo, quien me informó de la existencia de este importante trabajo. 
aunque se mostraban victimizados por su limitado poder, mantenían un silencio cómplice cuando de voluntad de cambio se trataba. El periodismo oficialista prosperaba en colusión con ese estilo político de los miembros de las instituciones de gobierno. Además, en su artículo señalaba las amplias posibilidades que tenía un senador para realizar cambios de fondo al sistema político. El periodista añadió que un senador leal al régimen se veía muy mal gimoteando por su poco rango de acción en épocas de comparsas nacionalistas conmemorativas del régimen de la Revolución, en comparación con el limitado papel que desde la prensa de oposición tenían los redactores de Política, pues en esta última "el periodista no tiene medios para realizar lo que plantea y la solución que ofrece”, so pena de ser aislado ya que "se le dice 'rojillo' exótico y no se le hace caso". ${ }^{14}$

Esta toma de posición de un académico activo en el periodismo y la vida pública se aunaba a múltiples voces que reclaman el retorno de la Revolución a su senda social, para así dar significado a un renovado y auténtico perfil "revolucionario", en contraposición con aquel que consideraba ampliamente manipulado por el poder. Dicho perfil involucraba como sus actores principales al periodista heroico, un ideal de intelectual integral y comprometido que a pesar de las inmensas dificultades impuestas a la prensa desleal al PRI, se expresaba a través de los órganos informativos de la oposición. Unos años más adelante, Enrique González Pedrero, junto con otros cuatro colaboradores, se distanció de la revista Política, atraído por los cantos de sirena en la alta burocracia. Este fue un acto que sirvió para demostrar la vulnerabilidad de los principios morales del periodismo, y que contribuyó a la formalización de un perfil heroico para la profesión cuando se la realizaba desde la plataforma crítica de la izquierda promediando la década de 1960. ${ }^{15}$

14 Enrique González Pedrero, “Una sinfonía revolucionaria...”.

15 González Pedrero se retiró de Política junto a Carlos Fuentes, Fernando Benítez, Víctor Flores Olea y Francisco López Cámara entre julio y agosto de 1964. Para una buena síntesis de los motivos y sus efectos para la izquierda y la revista, cfr. Patricia Cabrera López, Una inquietud de amanecer: literatura y política en México, 1962-1987, México, Universidad Nacional Autónoma de México/Plaza y Valdés, 2006. Aunque el retiro de estos cinco reconocidos intelectuales fue impactante para lectores y colaboradores, en la investigación se verificó que su colaboración a Política había declinado, y en el caso de Fuentes y Benítez, su participación como periodistas ya era menos que marginal desde comienzos de 1963. Este fue más un golpe público y mediático a la revista, pues en el fondo favoreció adhesiones más sinceras con el 


\section{Política, y el periodismo como desacralización}

El sopor que causaban los discursos oficiales en los que se repetían los nombres de los héroes del pasado para conjurar las dudas sobre el legítimo derecho a gobernar en el presente era apenas equiparable a los no menos extenuantes rituales de reactivación simbólica revolucionaria propagados en episodios épicos de adoctrinamiento escolar. Las exaltaciones, exoneraciones y acusaciones que animaban la vida política mexicana servían de insumo para actualizar la vigencia de las verdades emitidas por los textos escolares y cartillas cívicas usadas para adiestrar a la población en las artes revolucionarias. Como elementos de la cultura popular, los debates políticos y la pedagogía del régimen estaban a la orden del día. ${ }^{16}$ Manuales y actos cívicos reanimaban ciclos rituales vitales para mantener el ímpetu del sistema político mexicano. El elemento común era el uso de símbolos y creencias en las que "lo revolucionario" era la esencia que legitimaba la

proyecto de Manuel Marcué Pardiñas y los compromisos políticos que implicaba. De similar importancia pero mucho menos publicitada en los trabajos consultados fue la retirada primero de Salvador Novo, en mayo de 1963, y luego de Fernando Carmona a comienzos de noviembre de 1965. En el caso de Salvador Novo, de su parte hubo más bien un apoyo simbólico antes que periodístico, que resultaba del estilo personal del afamado escritor que decidía acercarse y/o retirarse de proyectos de sectores de la izquierda afines al régimen según la intensidad ideológica y el papel estratégico que podía jugar su nombre en el ámbito cultural dada la conveniencia de su cercanía con cada tendencia política. En el caso de Fernando Carmona, éste se había constituido desde 1960 en una figura importante para dictar la línea editorial de la publicación en temas de economía. Si bien la salida de Novo y Carmona estuvieron asociadas con el declinar de la figuración pública del Movimiento de Liberación Nacional (MLN), en general las desbandadas constituyen una importante evidencia de la red de asociaciones y guiños que hicieron posible la revista Política, y su instrumentalización como plataforma política y académica de reconocidos intelectuales mexicanos en la década de 1960. Estas desbandadas en el periodismo político y cultural de izquierdas en México, dejaron profundas cicatrices en el ejercicio del periodismo durante las décadas de 1960 y 1970; sin embargo, han pasado sin mayor análisis en los estudios de la izquierda contemporánea en México, y aun menos se la ha estudiado en trabajos sobre el periodismo de oposición en la segunda mitad del siglo XX, para el que Política aun es considerada un icono. Para una rápida ojeada a su significación, cfr. José Agustín, Tragicomedia mexicana, 2 v., México, Planeta, 1992.

16 Cfr. Illene O'Malley, Hero cults and the institutionalization of the Mexican State, 1920-1940, Nueva York, Greenwood Press, 1986; Charles A. Weeks, The Juárez myth in Mexico, Tuscaloosa, University of Alabama Press, 1987; Mary Vaughan, La política cultural en la Revolución: maestros, campesinos y escuelas en México, 1930-1940, México, Fondo de Cultura Económica, 2001. 
acción política como ritual. Política se sumaba a las escasas voces críticas al régimen, que intentaban perturbar el rumor compacto de las muchedumbres prosternadas ante el poder de las figuras místicas del pasado revolucionario.

Desde la revista se demandaba otro grito de independencia para así contraponer "el 'mitote' y el 'relajo' a que se presta la ceremonia del grito"17 y que sólo servía para reanimar al pueblo ante la creciente apatía por los símbolos patrios. Este artículo constituía la voz quincenal de la línea editorial de la revista cuando ya era identificada como la principal tribuna de oposición de la izquierda. Titulado "El grito y las libertades políticas", el editorial de la página cuatro complementaba esa voz editorial que en tono canónico buscaba responder interrogantes sobre el origen de las fuerzas cautivas que impulsaban la devoción popular, ese "secreto impulso que pone en marcha la espontaneidad del pueblo cuando se trata de confirmar su adhesión a la causa de la independencia del país". Se trataba de un fenómeno de masas que combinaba intimidación y apoyo, y una buena dosis de entrenamiento escolar, militar o incluso eclesiástico, pero que eran también el oficio de prácticas políticas que los periodistas de izquierda visualizaban como serias barreras para la efectiva operación de libertades democráticas como la expresión, el disentimiento y el ejercicio periodístico sin cortapisas. La devoción popular contenía una ambigüedad pues combinaba una "comunión de todo un pueblo con la sustancia original del amor a la libertad y la independencia”, pero expresada a través de una apropiación de los anclajes de la memoria social realizada por el estado. La evidencia de esto era un pueblo cautivo y devoto, arrastrado más por el miedo que por la convicción, y prisionero del temor a la represión a los disidentes, que si ocupaba las plazas en una homilía ante el poder del régimen era en buena medida por "la frialdad mecánica de los acarreos para recibir presidentes de la república”. ${ }^{18}$

Para entonces la revista ya había empezado a cosechar los dividendos más negativos de su audacia, pues su director y jefe de redacción recibieron

17 “México exige otro grito de independencia”, Política, México, D. F., 15 de septiembre de 1962, p. 2 de forros.

18 “El grito y las libertades políticas", Política, México, D. F., 15 de septiembre de 1962, editorial, p. 4 . 
a comienzos de 1961 unos cuantos macanazos y fueron conducidos ante las autoridades policiales para pernoctar en un calabozo, todo por manifestar su descontento por la visita del presidente peruano Manuel Prado, a cuyo paso frente al Hemiciclo a Juárez le gritaron “iViva Cuba!”, en alusión a la estrecha relación que establecía Perú con la OEA en contra de la soberanía cubana. Así, entre el grito en el Zócalo, y el grito de sabotaje a la honorable visita suramericana, Política se ganó un lugar especial en la repisa de los más valorados odios del régimen y sus organismos de fuerza. ${ }^{19}$ Las cartas de apoyo de lectores añadían aun más calificativos elogiosos a la encomiable labor de Manuel Marcué Pardiñas y su equipo de colaboradores en la redacción de la revista, elevando su status al de verdaderos adalides de la oposición de izquierdas en un momento en el que las divisiones entre partidos, sindicatos y movimientos sociales eran insuperables. ${ }^{20}$ La respuesta de los lectores era el contrapeso a las primeras manifestaciones de la represión contra Política. Mientras la revista mantuvo un pulso firme en la defensa de la Revolución cubana, y rechiflaba las vacilaciones diplomáticas frente a la soberanía de la isla y asuntos políticos internos, los lectores de la revista ayudaron a consolidar los primeros rasgos del periodismo de izquierdas como un acto valeroso, heroico, manifestación de la más alta responsabilidad revolucionaria, y que a menudo era equiparado

19 Manuel Marcué y Jorge Carrión, “Régimen policiaco?”, Política, México, D. F., 1 de febrero de 1961, p. 2 de forros.

20 Sobre la influencia de lo simbólico en la mística del régimen, y la visión que de ella tenía el periodismo de izquierda, cfr. Barry Carr, La izquierda... El reconocimiento que se le daba a periodistas como Manuel Marcué Pardiñas fue fundamental en la cimentación del ideal del periodista heroico como actor protagónico en la dialéctica política de la década de 1960 . El director de Política ejecutaba cada acto con una milimétrica precisión estratégica. En las memorias que consignó para la posteridad uno de sus sobrinos luego de la muerte del periodista -ya cuando era diputado del PRD-, se nota la importancia que Marcué Pardiñas asignaba a la acción política como una escena de mistificación personal, en la que la más alta manifestación de compromiso y sacrificio se sintetizaba en la compulsión que tuvo por morir en el palco público o durante una manifestación. Cfr. Carlos Perzabal Marcué, De las memorias de Manuel Marcué Pardiñas, México, Rino, 1997. Este trabajo también deja ver, en la entrevista transcrita a Raquel Tibol, las dificultades de las mujeres para destacar en el equipo de redacción de la revista, pues casi se podría hablar de un coctel de abusos laborales, acoso sexual y relentes xenofóbicos, lo que deja en claro que el periodismo como ámbito revolucionario era un espacio homosocial donde se refrendaban las características distinciones de género en lo profesional y lo político. 
con el más viril de los esfuerzos por devolverle la dignidad a la protesta social, después de que Adolfo López Mateos desencadenó la represión contra el movimiento ferrocarrilero y de maestros a finales de la década de $1950 .^{21}$

La fachada mitológica de la revolución se desboronaba, y con ella arrastraba el mito presidencial, arquetipo del poder político en México. Por ejemplo, Política alegaba en su tercer aniversario que "destruyó el mito y demostró que si algo enaltece y da vigor al ejercicio del supremo poder ejecutivo de la nación es someterlo a la inspección nacional, al análisis ponderado, pero firme y resuelto". ${ }^{22}$ El periodismo así se enaltecía de una función para reparar la moral social. Pero la denuncia de la mascarada mistificadora no se limitaba a los meses de mayor excitación nacionalista promovida por el partido de Estado. Cuando iba de salida de su cargo como presidente Adolfo López Mateos (1964), Manuel Marcué Pardiñas firmó la página editorial donde denunciaba cómo "se ha llegado al extremo de forjar una ficción de carácter ritual que ninguna persona sensata puede tomar en serio, y que nos convierte en el hazmerreír de cuantos extranjeros conocen nuestro país". El ritual era nada más y nada menos que la exoneración del presidente saliente, y la atribución de todas las fallas a sus colaboradores. Para los periodistas de oposición esto desestimulaba la evaluación crítica de cada gobierno desde la década de 1930, pero sobre todo desanimaba cualquier tentativa de buscar responsables reales de la debacle nacional. Dado que si “el presidente es intocable”, en general se hacía responsable al ministro del ramo en el que se producía el desacierto, "dejando en la impunidad la inmoralidad o la traición a los intereses colectivos".

21 Un buen ejemplo de la recepción del público juvenil de izquierdas respecto a la revista, y frente a la represión policial contra el periodismo de oposición, fue esta carta de la Federación de Estudiantes Técnicos a la redacción, enviada "a fin de difundir por medio de su prestigiada y viril revista, la carta suscrita por los delegados juveniles a la Conferencia Latinoamericana por la Soberanía [...] denunciamos el mundo que nos ahoga, el sistema de corrupción y desquiciamiento moral donde el hombre es enemigo del hombre. Los jóvenes de América Latina queremos que el hombre vuelva a ser el hermano del hombre. Así, la presente generación carga sobre sus espaldas la tremenda pero honrosa responsabilidad de retomar las banderas de San Martín, de Bolívar, de Artigas, de Martí, de Sandino, de Villa y de Zapata para liberar esta sufriente América india”. Correo, “La carta de la juventud”, Política, México, D. F., 15 de abril de 1961, p. 3.

22 "En el tercer aniversario de Política", Política, México, D. F., 1 de mayo de 1963, p. 34. 
En tanto promovía una vuelta al cauce de la Revolución de 1910-1917, Política debía ser iconoclasta y atreverse a quebrar a uno de los mitos más profundamente arraigados del régimen político mexicano que, a decir del director de Política, fue roto por la revista desde el primer día en un ritual de desacralización "señalando como primer responsable de la marcha del país al presidente de la republica". ${ }^{23}$ Lo importante de esta autoproclamación era que se promovía al periodismo no subordinado a las veleidades del poder del PRI como punta de lanza en la transformación política del país, y artífice del rediseño del material humano del panteón nacional.

De cara a la juventud: la crisis de las prácticas políticas y la mística nacionalista

De las prácticas políticas que emanaban directamente de la presidencia de la república, tres merecieron particular atención en artículos relacionados con la crisis mística de las ceremonias propias del patriotismo mexicano. De antemano, vale la pena mencionar que todas tenían en común, además, el que hacían evidente una crisis de las narrativas que exaltaban la gloria eterna de la Revolución mexicana. En primer lugar, el "tapadismo", "un acto de interpretación del papel de los héroes mexicanos como una actividad sobrenatural, colocada por encima de las masas" que, como ejercicio de la sucesión, indicaba la índole autoritaria y personalista del régimen, así como la dudosa pausa de transmisión del poder a lo largo de medio siglo y una docena de generaciones. A esta práctica la antecedía un ritual interno del poder por el que se exasperaban las fuerzas políticas en las instituciones del Estado; se trataba del "futurismo", un acto sigiloso por el cual el presidente manejaba sus influencias personales para dotar al futuro candidato del PRI de las claves ocultas y el aura honrosa de la sucesión presidencial. Como en un acto de prestidigitación, el "futurismo" era el preludio a "las maniobras de designación presidencial a espaldas del pueblo" por el cual el ritual de la transmisión del mando adquiría "un carácter místico heroico que consagra al tapadismo como algo lícito, inherente a la condición de herederos de Hidalgo, Morelos, Juárez, y Madero”. En tanto la decisión de 1964, p. 2 de forros. 
emanaba del ejecutivo, la tradición en la sucesión ininterrumpida servía como una pátina legitimadora refrendada en la legalidad del sufragio popular. Pero el cambio de piel del régimen era posible por un diálogo que presidente y mártires de la patria alcanzaban para sublimar la naturaleza sobrenatural del sistema político posrevolucionario. La demagogia alcanzaba allí tonos sobrenaturales, pues así se consagraba al candidato del PRI como el ungido, en un proceso de selección personal refrendado en comicios marcados por el fraude, que mostraba a los héroes como cómplices “abstraídos de la realidad, hechizos y estáticos... Tapados". ${ }^{24}$

En segundo lugar estaba la declinante eficacia del paternalismo presidencial hecho ritual y doctrina a través del ideal de la "familia revolucionaria”. El sistema político, atiborrado de caudillos y sumergido en el burocratismo, mantenía aceitada una maquinaria que rehusaba transformarse, pero que renovaba sus bríos cada seis años en las elecciones. La falla del sistema posrevolucionario estaba en que "al corroer la punta del lema $\mathrm{Su}$ fragio Efectivo, No Relección, destruye también su cabo: la no relección es ficticia, no va más allá de una simulación bajo la cual el continuismo de los hombres, métodos y política aparece con el nombre de la 'Familia revolucionaria', con el carácter de nepotismo oficial”. ${ }^{25}$ Ficticio o no, las críticas

24 La transición política que significaba la elección presidencial, que ya en la década de 1960 constituía casi un ritual con los rigores de "las conmemoraciones oficiales patrióticas y que ofrecen un ancho cauce a los torrentes de la oratoria oficial”, fue en 1963 y 1964 un motivo para altisonantes editoriales de Política, entre los que destaca uno titulado "Fiestas patrias, héroes acartonados y 'tapadismo' ”, Política, México, D. F., 15 de septiembre de 1963, p. 2 de forros. Cabe anotar que las réplicas de los tremores del sistema simbólico del poder en México afectaba a Política, pues fueron usados como excusa para el retiro de Carlos Fuentes, Fernando Benítez, Enrique González Pedrero, Víctor Flores Olea y Francisco López Cámara. En esa ocasión, el apoyo del general Lázaro Cárdenas a la candidatura de Gustavo Díaz Ordaz desencadenó furiosas críticas contra su figura, tildada de anacrónica y traicionera al proyecto político del MLN. Estas exhortaciones sirvieron a esos cinco intelectuales como excusa para retirarse del equipo editorial de la revista. Patricia Cabrera analiza con acierto la forma como el motivo real de su separación de la revista fue la efectividad de los mecanismos de cooptación en la nómina del nuevo gobierno. También debe añadirse la profunda lealtad de Carlos Fuentes hacia Lázaro Cárdenas, desarrollada a lo largo de las primeras travesías por el país tras la creación del MLN en 1960 y 1961; y una ponderación de las implicaciones de mantener un compromiso con la revista, cuya línea crítica frente al régimen no cedería hasta el cese de su publicación. Cfr. Patricia Cabrera López, Una inquietud..., p. 45-67.

25 Jorge Carrión, “La no relección, disfraz de caudillos burocráticos”, Política, México, D. F., 1 de octubre de 1963, p. 7. 
que canalizó Política contra el sistema electoral y los rituales que perpetuaban prácticas políticas que impedían el funcionamiento de la democracia apuntaban al sistema en general y los efectos que tenía sobre la participación política juvenil. Las atribuciones del poder político, coronado por el presidencialismo y refrendado en el "tapadismo", la corrupción y la reverencia acrítica hacia el jefe de Estado, tenían en el sistema educativo un espacio central para inspirar asombro, respeto y temor a las nuevas generaciones con los rasgos sobrenaturales de la continuidad revolucionaria, a través de la idea de pertenencia a una unidad integradora de las instituciones públicas. $\mathrm{Al}$ régimen, por ejemplo, se le cuestionaba la celebración casi supersticiosa de los hitos históricos y la renovación democrática presidencial en el mes de noviembre, cuya paradójica naturaleza hacía difícil discernir al cuerpo editorial de Política si ésta era una fiesta o unas exequias, puesto que constituían un formalismo para "mantener los intereses de la 'familia revolucionaria' sobre el monopolio de un partido que sólo es agencia burocrática electoral”. ${ }^{26}$

Estas prácticas impedían la renovación del PRI y de las personas que conformaban sus organismos estatales, donde se auguraba una importante responsabilidad para los jóvenes, que tendrán "un papel decisivo en la superación de la crisis de México si saben interpretar los signos del tiempo y si saben, valga la expresión, ser jóvenes". ${ }^{27}$ El artículo de Enrique González Pedrero se preguntaba por el lugar donde estaba la novedad, la rebelión y la juventud en el PRI, de cara a las iniciativas frustradas de sus células juveniles por incorporase a posiciones de liderazgo. Aunque basado en el prejuicio que pendía sobre la juventud como agente de rebeldía y cambio, el comentario del periodista aludía a las mínimas transformaciones del partido de gobierno que al elegir nuevos cuadros "integrados por jóvenes militantes del PRI han sido barridos literalmente por las viejas carcachas", solamente posponía la fecha para que el régimen cambiara desde adentro, legando así una mayor responsabilidad moral a los jóvenes. ${ }^{28}$

26 “Fiestas o exequias?” (editorial), Política, México, D. F., 15 de noviembre de 1960, p. 4.

27 Enrique González Pedrero, “La crisis llega al PRI”, Política, México, D. F., 15 de abril de 1961, p. 21.

28 Las consideraciones paternalistas que nutrieron la mística política mexicana tenían en la idea de la "familia revolucionaria" un tapón que impedía la inclusión de mujeres y jóvenes en la vida pública del país. Si bien era un problema común en las democracias y regímenes 
Años más tarde, ante la inminente elección de Gustavo Díaz Ordaz como presidente en 1964, el temor a que se repitieran las maniobras evasivas contra la renovación generacional en los altos cargos se reflejó en las páginas editoriales de Política, donde se elevó la siguiente súplica:

Con todo lo que la juventud tiene de respetable -y lo más honroso que posee es su sentimiento revolucionario, hoy harto adormecido en la juventud afín a la burguesía-, lo que importaría sería que el nuevo gabinete estuviera integrado con gente nueva -joven madura o viejaen el sentido de nuevas concepciones e ideas que permitan romper un cerco que ha impedido planificar las actividades intersecretariales como lo necesita hoy el país. ${ }^{29}$

El clamor por un cambio era contundente, justificado en la decadencia del discurso de la "familia revolucionaria"; sin embargo, no era claro para la izquierda cuál debía ser el papel juvenil, ni los mecanismos institucionales por los que debería operarse, ni la naturaleza de una inminente renovación, ni mucho menos la forma de su vinculación al sistema político. Esto es una muestra de la forma como Política reproducía la estigmatización que el régimen y la sociedad hacían de los jóvenes pese a tener como plataformas ideológicas perspectivas incluyentes de este nuevo actor político. Política aún no desplegaba en sus páginas editoriales algún indicio sobre la forma cómo la juventud podría integrarse a la participación en manifestaciones opositoras, y más bien mantenía una posición ambigua sobre este sector social emergente en la escena política nacional. En su lugar, algunos de sus colaboradores mantenían posiciones fundadas en prejuicios y estereotipos sobre el nivel cultural, las condiciones socioeconómicas o las inclinaciones ideológicas con los que

autoritarios de Occidente, en el caso mexicano significó una fuente inagotable de imágenes de subordinación y condescendencia que se fracturó con la masacre de Tlatelolco. Revistas como Brecha: por la superación de México y Caridad y Patriotismo: órgano de la Cruz Roja de Cuautla fueron parte de la muestra hemerográfica consultada. Ambas publicaciones, entre muchas otras, ofrecen una ventana privilegiada para reconocer las pautas educativas y cívicas por las que se institucionalizó el tono condescendiente que el Estado tenía hacia mujeres y jóvenes del país.

29 “Editorial”, Política, México, D. F., 1 de octubre de 1964, p. 3 de forros. 
los jóvenes podrían contribuir en la lucha contra el monopolio político del PRI y el Estado.

Finalmente, en las páginas de Política se condenaba el informe anual del gobierno como un acto de exculpación presidencial, "una ceremonia convertida por repetición y cansancio del público en meros ritos compulsivos, como los que aquejan a Pilatos en conflicto con una conciencia cuya suciedad no se queda en el aguamanil simbólico”. En efecto se lo veía como un ritual presidencial orientado a lavar sus manos liberando su investidura de toda falta, y por el cual se transmitían las culpas a funcionarios cercanos que animaban en adelante debates que servían de cortina de humo hacia la sucesión. Política veía este proceso como oneroso para la salud democrática del país, en un sistema político cada vez más cargado de pecados y sin mecanismos para expiarlos. Esto permitía que la legitimación del poder y el tránsito del presidente al panteón de los héroes se realizaran sin que hubiera profanaciones sobre su inmaculada imagen. El agente legitimador era una vez más un elenco popular de "cadetes, obreros acarreados, burócratas que firman listas de asistencia, vocinglería de la radio y la televisión”. Esta evidencia del traspaso acrítico del poder, su reforzamiento en un proceso de sucesión altamente simbólico, y el vaciamiento de cualquier sentido democrático que padecía, marchitaban la vitalidad mística del sistema político mexicano, que tenía en el bálsamo del sufragio popular, la cooptación o la coerción sus fuentes de rejuvenecimiento. ${ }^{30}$

Dos años después, Jorge Carrión reiteraría estas denuncias señalando que "no hay uno de estos [gobernantes] que no pregone, como lo acaba de hacer Gustavo Díaz Ordaz, 'moralidad pública' " un formalismo que "el gang corrompido que periódicamente efectúa ostentosos actos de contrición o cada sexenio repite con la admonición a la 'moralidad pública'". ${ }^{31}$

El común denominador de estos aspectos críticos que rodeaban las prácticas políticas en México en los años 1960 era la fuerza cohesiva de

30 Jorge Carrión, “El informe, aguamanil de Pilatos”, Política, México, D. F., 1 de septiembre de 1962, p. 10.

31 Jorge Carrión, “La corrupción, símbolo del 'gang' en el poder”, Política, México, D. F., 15 de septiembre de 1964, p. 11. Subrayado en el original. 
la figura presidencial como representante del régimen. A los ojos de la izquierda convocada en la redacción de Política, la figura presidencial estaba afectada por una profunda crisis de legitimidad y reconocimiento popular. Los formalismos simbólicos y místicos han sido estudiados en las ciencias sociales mexicanas. ${ }^{32}$ Sin embargo, parece necesario mencionar que uno de los mecanismos que hacía funcionar la aceptación popular de los líderes políticos era la práctica paternalista de la condescendencia. Su importancia, como veremos en la siguiente sección de este trabajo, está en la relación que el periodismo de oposición le atribuyó a la educación pública, y el despegue juvenil en su intervención en asuntos políticos promediando la década de 1960. La actitud paternalista estuvo presente a todo lo largo de la doctrina pedagógica, política y cultural que constituía la "gran madurez cívica y política del pueblo mexicano”. Según Jorge Carrión, tal madurez no era otra cosa que una estrategia para fortalecer el conformismo social y sostener un esquema autoritario en crisis. Se trataba pues de una "estúpida moraleja” de las clases dirigentes -a las que denominó “minorías privilegiadas, ahítas e insolentes"- que penetraban en la población por la vía de la "escuela, libros de texto y discursos de corte panteón heroico [que] se proponen mantener al pueblo alejado de la participación verdadera en los bienes de la civilización”. Esa moraleja era dirigida a los jóvenes en la enseñanza pública o privada, promoviendo una historia oficial inscrita en textos gratuitos "atiborrados de anecdotismo ramplón". ${ }^{33} \mathrm{Si}$ el futuro político de México estaba en la eficaz acción de la izquierda para integrar a la juventud en el debate de los problemas que erosionaban los principios de la Revolución mexicana, el periodismo opositor de Política debería esclarecer los puntos de falla en esa promoción de la renovación mística que elevaría la "autoridad moral" de los actores sociales encargados de devolverle la lozanía a la demacrada gesta de comienzos del siglo XX.

En conclusión, buena parte de los anclajes místicos que sustentaban el poder político mexicano se articulaban a través de narrativas de lo heroico, el sacrificio y la abnegación conformista, de las cuales la misma izquierda habría de hacer uso para aprovechar la crisis moral del régimen y

32 Cfr. William Beezley, op. cit., p. IX-XVII.

33 Jorge Carrión, “La famosa 'madurez política del pueblo' ”, Política, México, D. F., 15 de mayo de 1964, p. 13. 
la decadencia de su fachada simbólica. Como veremos, tales narrativas oficiales operaban a través de la educación pública y empezaron a orientarse en el discurso moral de la izquierda hacia el reconocimiento de la valiosa contribución que hacían maestros, periodistas y líderes sociales a través de su accionar heroico.

La educación juvenil: moral, pedagogía y la crisis del oropel nacionalista

La línea editorial de Política se servía de la realidad cotidiana mexicana, y ocasionalmente de los clásicos, para denunciar las desviaciones del régimen. Tal es el caso de un interesante examen de los mitos en México, donde recordaban la advertencia de Flaubert sobre el peligro que representaba tocar a los ídolos de oro, ya que en general "algo se queda entre los dedos". ${ }^{34}$ En su intento por interpretar la Revolución, Política apelaba a otros ejemplos revolucionarios fallidos o referentes de la mística nacionalista para explicar su desviación de los ideales originales. Sin embargo, los procesos sociales que más interesaban a los periodistas de Política, eran aquellos que demostraban las contradicciones internas de la sociedad, de donde afloraban concepciones divergentes del mundo apoyadas en marcos morales con los que se juzgaba una situación como buena o mala. Aunque muchos de los debates políticos relacionados con la Revolución demostraban los antagonismos sociales que antecedieron su estallido en 1910, Ermilo Abreu, escritor, catedrático y quizá el periodista más prolífico de aquellos que pasaron por la redacción de la revista, señaló que dichas diatribas eran más bien

sofismas que son capaces de burlar la razón misma, para presentarse como arma política y hasta como arma social en la lucha de dos fuerzas: la que arrastra al pueblo mexicano hacia la incapacidad de la libertad espiritual y la que lo pone en camino de emplear su propia y libre razón para buscar la verdad, la verdad humana, no la que se guarda, estéril 
o inútil, en la nuez de los dogmas, de cualquier dogma, de cualquier religión. 35

El columnista hacía referencia a las constantes tensiones que acompañaron el gobierno de Adolfo López Mateos por el tema de los libros de texto y la intromisión de la Iglesia y particulares en la definición de la política educativa nacional.

Este comentario reviste interés, por coincidir con algunos de los factores que resultaban importantes a la hora de promover visiones morales del mundo al interior de la revista Política. En efecto, Abreu hacía referencia al lugar que ocupa la verdad en la búsqueda de la libertad espiritual. En su percepción, de la libertad en el ejercicio de los oficios de escritor, periodista y profesor -todas profesiones en las que él mismo se destacaba- se definía la relación de una sociedad con la verdad y su influencia sobre la opinión pública. Abreu mostró preocupación por diversos temas, pero el de la libertad de los presos políticos -a quienes veía como artistas, periodistas y pensadores antes que como simples simpatizantes de una causa política-y la educación predominaron en sus columnas entre 1960 y 1967. De especial interés para este artículo, fue el tratamiento a temas que él y otros colaboradores de Política dieron a la problemática educativa y la forma como niños y jóvenes resultaban representados en esos debates. Allí era posible, a decir de Ermilo Abreu, entender los valores y comportamientos que definían el perfil moral de las diferentes posiciones políticas en el país. Continuaba así el comentario del periodista:

La orientación moral y espiritual de los niños mexicanos no puede estar a merced ni de la inteligencia ni de la ignorancia de los padres. No puede estar a merced ni de la buena fe ni del sentido arbitrario de los padres. La educación, la total educación de la niñez y de la juventud, corresponde a los deberes superiores que exige la patria. Así como existen leyes que obligan a todos los ciudadanos, así tienen que existir normas educativas que garanticen un coherente deber social, un sentido de moral colectiva, una inaplazable obligación de actuar con 
libertad racional, con libertad de doctrina dentro del derecho superior de la patria. ${ }^{36}$

El debate sobre la educación

En el México contemporáneo, y como uno de los legados más apreciados de la Revolución, la educación se había constituido en uno de los baluartes del cambio social e insignia de la influencia del Estado sobre los ciudadanos. La relación entre el Estado y la ciudadanía estaba en gran medida determinada por el afán de salvaguardar el derecho constitucional a recibir una formación idónea, y esto predominaba sobre los intereses individuales o las creencias religiosas familiares. Aunque esa obsesión del régimen por seguir la Constitución de 1917 no se correspondía con otros problemas, como el respeto a la disidencia o las opiniones críticas al régimen, es un fenómeno que permite reconocer los límites impuestos por el Estado a la noción de ciudadanía. Hacemos referencia en particular a la forma como se promovió una visión condescendiente hacia la juventud, que favorecía prácticas paternalistas que resultaban reflejadas inclusive al interior de los grupos antagonistas del partido de gobierno. Política sirvió como una plataforma para la discusión de este tema, de donde surgieron interesantes puntos de vista sobre la juventud, la moral y el papel de quienes dedicaron su vida a la docencia como parte de un compromiso social y revolucionario.

El tema promovía manifestaciones, escaramuzas de combates y golpizas de la policía, y despertó fricciones en los sectores involucrados en la definición de la política educativa de México. La tensión entre el gobierno, la iniciativa privada y la Iglesia católica frente al tema de la educación y los textos gratuitos no representaba un factor de conflicto o inestabilidad tan profundo como lo fue la oposición religiosa a finales de la década de los 1920. Sin embargo, en esta sección se quiere hacer un seguimiento a las facetas de este debate y el papel que tenía la juventud dentro de las visiones morales de la izquierda mexicana, pues se trataba de una generación que demandaba acceder a una completa integración en los procedimientos que formalizaban la naturaleza democrática del sistema. 
Como ya vimos, esto ocurría justamente en el momento en el que la fachada simbólica del poder político pasaba por uno de sus peores momentos.

En alusión a las prácticas pedagógicas y la férrea oposición organizada por la burguesía y la Iglesia católica, Jorge Carrión hizo un llamado para "Desmitificar al pueblo mexicano" ${ }^{37}$ Así tituló su Columna dedicada a criticar los modelos de heroísmo de las gestas nacionales propagados en la educación. Según el periodista, los textos gratuitos "se convierten en auxiliares de la deplorable tarea de sustituir con mitos la realidad”. De ese "oropelesco ambiente oficial de mitos y ruidosas, inútiles palabras" que era la educación -donde se bautizaba a los niños y jóvenes en las aguas marciales de la Revolución mexicana y se impartían los valores cívicos de su orientación democrática-, surgía finalmente la demagogia que sostenía "la actual burguesía en el poder", que ponía su nombre para ser exaltados en "discursos oficiales ante los indefensos, incapaces de bajar de sus pedestales", pues mientras el régimen imponía en la memoria social las hazañas de Venustiano Carranza, los "sectores campesinos [...] prefieren dar su veneración a las de Emiliano Zapata”. La población tenía su propio panteón heroico, con narrativas divergentes de la versión oficial, y apoyadas en unas conmemoraciones promovidas como expresiones de disidencia. Jorge Carrión, académico vinculado a la UNAM, militante del PP, y luego animador destacado del MLN, veía la educación como parte del juego demagógico animado por los héroes seleccionados del pasado nacional que mejor convenían para perpetuar el poder del PRI como quintaesencia de "lo revolucionario".

La línea editorial de la revista describiría al año siguiente (1964) la robustez del proceso por el que el régimen adoctrinaba a la ciudadanía desde la niñez, que pese a no configurar una ideología clara, sí promovía un pragmatismo voluble y dependiente de las derivas presidenciales. A través del editorial "La educación particular: rapiña, comercio y anticonstitucionalidad", ${ }^{8}$ la revista continuaba una crítica del arsenal ideológico del régimen, que no se limitaba a las instituciones del Estado, pues incluía la

37 Jorge Carrión, “Desmitificar al pueblo mexicano”, Política, México, D. F., 1 de junio de 1963, p. 14 .

38 "La educación particular: rapiña, comercio y anticonstitucionalidad”, Política, México, D. F., 1 de noviembre de 1964, p. 3 de forros. 
Iglesia católica y los tentáculos económicos de elites dispuestas a imponer una educación favorable a sus intereses:

Desde hace largas décadas la educación oficial carece de doctrina, es sólo un cascarón lleno de confetti cívico tricolor, de anécdotas históricas y estampitas de héroes, mientras que la de índole particular es un huevo podrido, pletórico de veneno contra todo lo que en México ha sido progreso y adelanto, y de insidia contra cualquier intento de abrir ante los ojos de la niñez y la juventud mexicanas perspectivas de una vida social mejor. ${ }^{39}$

Para el régimen político mexicano, el sustento en la educación pública estaba en proceso de consolidar una mecánica guiada en los preceptos constitucionales y la iniciativa de proyectar a nivel nacional el uso de los textos gratuitos definidos por la Secretaría de Educación. ${ }^{40}$ Las medidas, que venían siendo implementadas desde la década de 1930, habían tenido interrupciones y serias oposiciones, pero el régimen había logrado imponer premisas educativas que se correspondían con la trayectoria de una cultura popular favorable a la versión oficial del pasado, el presente y el futuro de la Revolución mexicana. ${ }^{41}$

En otra columna de mediados de 1963, se denunciaba la estrecha relación que tenía la iniciativa privada y la Iglesia católica en sabotear la iniciativa gubernamental, ejecutada de forma sigilosa a través de las pastorales que "son una vez más una declaratoria contra el artículo 3o.", y ante lo cual el Estado tenía poco rango de maniobrabilidad. En efecto, a la retórica nacionalista del partido de gobierno y sus entidades burocráticas, las pastorales contraponían un andamiaje similar, que ubicaba a la juventud y la niñez en el centro de los esfuerzos de la triada Familia-EstadoIglesia, donde se naturalizaba al niño para su tránsito hacia la madurez política. Explicaba en el artículo, que

39 Idem.

40 Cfr. Mary Vaughan, La política cultural...; Valentina Torres Septién, La educación privada en México: 1903-1976, México, El Colegio de México/Universidad Iberoamericana, 1997.

41 Cfr. Mary Vaughan, Estado, clases sociales y educación en México, México, Fondo de Cultura Económica, 1982; Mary Vaughan et al., The eagle and the virgin: nation and cultural revolution in Mexico, 1920-1940, Durham, Duke University Press, 2006. 
las comunidades en que aparece y se desarrolla el niño [...]. La familia es por derecho natural la primera sociedad a la que el niño pertenece [...]. El niño pertenece ante todo a su familia, y ésta tiene un derecho sobre él primario e inalienable [...]. La Iglesia, por mandato de su Divino fundador, tiene el deber y el derecho de impartir la enseñanza religiosa y de intervenir en la formación moral de las personas.

De tal forma, se relegaba a un plano secundario la función del Estado y la educación pública escolar cuando no fuera confesional. En el fondo estos comentarios contienen un sesgo paternalista y condescendiente frente a la niñez y la juventud, al inscribirlos en un debate sin mayor posibilidad de que éstos verbalizaran intereses, iniciativas o posibilidades alternativas, pues entre los rasgos del régimen y su incidencia en la sociedad estaba la adopción de la línea institucional como el derrotero ideológico, o ante la ausencia de un sistema de creencias, la sustancia moral para un comportamiento idóneo y constructivo. No podía esperarse menos, pues una década después, cuando los jóvenes contaban con el derecho al sufragio, sus decisiones estaban acompañadas de discursos canónicos que proliferaban en la prensa y otros elementos de la cultura popular mexicana. Si bien Política abordaba la temática infantil y juvenil, no proponía posibilidades por fuera de ese trato condescendiente que legaba un lugar subordinado para aquellos que aún debían transitar las aulas para alcanzar la madurez política que tanto se arrogaban y reprochaban mutuamente la izquierda y el régimen.

El poder desestabilizador del debate político sobre la educación, dependía en buena medida de la efectiva expansión de una cultura popular arraigada a la narrativa épica de la nación, en la que la "familia revolucionaria” constituía un baluarte de integración social e identificación individual, además de ser el horizonte de desempeño profesional y fuente de la movilidad social..$^{2}$ Ahora será necesario examinar con mayor detalle el tema de los libros de texto y la pugna generada en torno a la educación pública. 
Libros de texto, fallas de la educación y la cultura popular

A lo largo de 1962 parte del debate político fue protagonizado, de una parte, por los actores sociales que promulgaban la educación pública como premisa para la corrección del rumbo moral de la Revolución mexicana, y de otro lado, por los defensores del libre albedrío de los ciudadanos que al reclamar el derecho a optar por la educación que mejor representara los valores aprendidos en el hogar hacían uso de sus derechos, consagrados en la Constitución de 1917. Estos últimos veían esos derechos obstaculizados por la influencia del Estado en temas educativos. ${ }^{43}$ Del lado de la izquierda, se reconocía la insuficiencia de la educación sobre todo en el contexto rural, donde la falta de escuelas y maestros, y las pugnas al interior del SNTE hacían del papel de los maestros mexicanos "una heroica lucha" que promovían a los adultos del futuro "desde el jardín de niños hasta la universidad". ${ }^{44}$ En las ciudades no era mejor el panorama, pues al crecimiento de los cinturones de miseria y las dificultades de núcleos familiares para promover que los jóvenes ascendieran en la escala social se le sumaban las jornadas de pánico moralista que desde finales de la década de los 1950 ocupó extensos editoriales de la "Gran Prensa" con el tema de los "rebeldes sin causa". ${ }^{45}$ Los jóvenes se habían robado la atención pública y congestionaban la producción de imágenes estereotipadas para alimentar la cultura popular, ya fuera por sus excesos de violencia, beodez, desobediencia de las normas hogareñas, o actos de irreverencia con las convenciones sociales. ${ }^{46}$

43 Cfr. Valentina Torres Septién, "Estado contra Iglesia/Iglesia contra Estado. Los libros de texto gratuitos: ¿un caso de autoritarismo gubernamental 1959-1962?”, Historia y Grafía, Mexico, D. F., Universidad Iberoamericana, 2011, p. 19-37.

44 José Santos Valdés, “Tareas políticas del magisterio”, Política, México, D. F., 1 de enero de 1962 , p. 36.

45 Cfr. Eric Zolov, Rebeldes con causa: la contracultura mexicana y la crisis del Estado patriarcal, México, Norma, 2002; Larissa Adler de Lomnitz, Cómo sobreviven los marginados, México, Siglo Veintiuno Editores, 1985; Oscar Lewis, Los hijos de Sánchez, México, Grijalbo, 1982.

46 Como parte de esta investigación, se revisaron los editoriales del periódico La Prensa entre 1958 y 1962. Uno de los temas centrales en dichas secciones fue la educación pública, la inoperancia de los maestros sindicalizados, la pérdida de un horizonte moral para la juventud, la pérdida de valores en la sociedad mexicana y el creciente ensalzamiento de la Iglesia en la educación que recibirían los niños y jóvenes del país. La gran paradoja de esta línea editorial de La Prensa era el creciente volumen de páginas dedicadas a promover películas 
Las insuficiencias del sistema público también tenían relación con aspectos de discriminación por factores de clase, lo que determinaba la calidad de la enseñanza y el compromiso de los instructores. Estos aspectos también se vieron reflejados en los argumentos desarrollados en las páginas de Política. El primero se debía a reflexiones en torno a la insuficiencia de recursos públicos invertidos, que promovía la idea de uniformizar a la niñez mexicana con el rasero de las clases más necesitadas en lugar de promover la excelencia según un modelo más competitivo que le diera a cada quien según sus medios y capacidades. En un artículo contra las marchas realizadas en Nuevo León a comienzos de 1962, Juan Duch apuntaba desconcertado cómo los padres de familia "proclamaban patéticamente que la educación oficial es nociva", promoviendo distinciones por motivos socioeconómicos desde la escuela. "En las escuelas particulares -las buenas, según ellos- fijan altas colegiaturas para evitar contaminaciones con la plebe, y no se conocen muchos casos en que con su dinero sostengan escuelas gratuitas. Si acaso una o dos en toda la república, y con discriminación: aquí los ricos, allá los pobres". ${ }^{47}$ Además de los anatemas con los que se describía la instrucción pública, la imposición de textos se rechazaba por la aparente incoherencia en su elaboración, a lo que la revista Política dio menos importancia en sus páginas, excepto con referencia a los contenidos

estadounidenses donde se promovía la rebeldía juvenil, y más aun, el robustecimiento de su sección promocional de productos con modelos femeninas ligeras de ropa, o shows para un público adulto masculino. Pero no había contradicción en esa tendencia, pues si leyendo el periódico un ciudadano del común se sentía tentado a ir a un cabaret de la Calle del órgano y aledañas, fácilmente podría saltar a las páginas finales del periódico, donde se anunciaba a diario con gran expectativa la próxima inclusión de alguna efigie del santoral católico. Política tocaba mucho menos esta problemática en sus primeros años, y sólo lo haría de forma más sustancial desde 1963, ya fuera a través de cartas enviadas por lectores (cfr. "El pandillerismo", Política, México, D. F., Correo, 1 de septiembre 1963, p. 3) o a través de exaltaciones realizadas principalmente en tres temas: 1 , asuntos internos en la UNAM, relacionados casi siempre con la rectoría; 2, el ejemplo de las movilizaciones en Estados Unidos contra las armas nucleares y en favor de la expansión de los derechos civiles a los afroamericanos; 3, participación juvenil en política nacional, en buena medida influenciado por las protestas estudiantiles en Michoacán y Puebla y luego por la represión a marchas contra la guerra en Vietnam desde 1965. Las oportunidades en las que en Política se trató el tema juvenil fueron cuando éste estuvo relacionado con manifiestos programáticos del MLN, o formaba parte de documentos producidos en la URSS o Cuba.

47 Juan Duch, “Derecha: teoría de la simulación”, Política, México, D. F., 1 de marzo de 1962, p. 32. 
que exaltaban el nacionalismo o que explotaban aspectos culturales como folclore.

En materia de los recursos públicos usados para la educación, la polémica involucró a uno de los principales columnistas encargados de temas económicos. Enrique González Pedrero, también catedrático de la Escuela de Economía de la UNAM como Jorge Carrión, y quien había publicado libros colectivos sobre el desangre económico mexicano operado desde la iniciativa privada -principal actor tras bambalinas del movimiento de padres de familia en Nuevo León-, tildó de ingenua la forma como Jaime Torres Bodet, secretario de Educación Pública de Adolfo López Mateos, promovió un diálogo en el que le pedía a la iniciativa privada que "sacrificara una parte de sus ganancias" para resolver el problema educativo del país. El periodista exigía al gobierno, como un acto de justicia y sensatez, la corrección de los instrumentos fiscales del Estado para que las escuelas contaran con un mayor y más estable flujo de recursos, en lugar de fomentar la subsistencia del sistema educativo a través de "la limosna de los ricos". ${ }^{48}$ Estas manifestaciones de incomodidad ante los reclamos de padres de familia, al igual que muchas otras que se reprodujeron en Política en 1962, coincidían en apuntar a la Iglesia católica como artífice de las iniciativas orientadas a debilitar la posición del Estado, usando como soporte moral la doctrina religiosa y no un modelo civil que validara las premisas constitucionales.

En términos de calidad de la educación, es necesario destacar que las intervenciones de la izquierda se orientaron más a criticar artefactos propios de la cultura popular, que a atender el problema de fondo de la instrumentalización de los libros de texto escolares para adoctrinar a niños y jóvenes. Esto le imprimía a su concepción del problema claros visos moralistas. Por ejemplo, un mes después de escribir el artículo antes mencionado, Juan Duch sostuvo que había una contradicción profunda en el reclamo de las elites, pues a pesar de la "torturante amenaza que para la integridad moral de sus hijos constituyen los libros de texto gratuitos”, y el peligro que esto implicaba para "el porvenir de la patria", la supuesta amenaza que el Estado imponía al rol paternal en los hogares mexicanos pasaba por alto peores atentados contra el niño" ya que "nadie reprocha ni se confiesa culpable de 1962, p. 16. 
las pantallas panorámicas, en televisores, los cómics, las páginas rojas -esas, sí rojas- de la prensa diaria; en los lujos de última moda, en los geniales slogans publicitarios que estimulan el gasto superfluo, en las inocentes pistolas que se exhiben en los escaparates de las jugueterías, en el "panchopanterismo' que se inculca en las mentes infantiles”. ${ }^{49}$ En su opinión, ese debate era una excusa para obstaculizar al gobierno en sus propósitos de masificación educativa, y para lanzar anatemas contra la izquierda. No se trata de denunciar aquí estos comentarios como falsos, pero es necesario anotar que el periodista promovía una visión que más bien negaba la influencia que venía ganado la cultura popular en todo el planeta, y comentarios suyos sobre ritmos como el twist estaban cebados de intransigencia contra las tendencias que más atrapaban la atención juvenil.

En 1964 la línea editorial de Política manifestó un parecer similar, señalando la forma como la educación pública, que apenas si podía sacar del pozo del analfabetismo a un porcentaje irrisorio de la población, poco podía hacer frente a las

deplorables legiones de semianalfabetos -niños, adolescentes, adultos- que sólo leen historietas ilustradas con pésimo gusto, pornográficas o torpemente macabras, cuando no traducidas de las que en EU sirven de vehículo de propaganda a la guerra fría y se difunden en México como muestra grosera de deformación de la cultura y de la vida policía del país. ${ }^{50}$

Aunque la revista no tenía una línea de opinión respecto a la cultura popular, sus colaboradores sí zanjaron el debate aseverando con frecuencia la imposible relación entre el pensamiento de izquierda, el compromiso político y determinados géneros musicales, poéticos o artísticos. Esta actitud intransigente explica la divergencia de criterios y horizontes de la juventud movilizada en 1968 frente a la izquierda tradicional. En el monólogo del periodismo de izquierdas, la cultura popular siempre fue una de

49 Juan Duch, “El susto de los padres de familia”, Política, México, D. F., 15 de mayo de 1962, p. 32.

50 Editorial “Educación para liberar o para encadenar al semialfabetismo?”, Política, México, D. F., 1 de septiembre de 1964, p. 4. 
las peor libradas derivando en la incomprensión entre actores que veían al mundo desde distintos sistemas de creencias, reglajes morales y convicciones respecto al significado de la política como camino a la democracia. Muestra de ello, fue el amplio despliegue que se le dio a la producción artística y la acidez crítica en temas como las historietas, la pintura abstracta o el cine comercial.

Más allá de los típicos argumentos relacionados con la alienación que la cultura popular imponía a los jóvenes, existía una reluctancia a incorporar miradas alternativas que representaban los intereses juveniles. Esa negativa significó la faceta más marcada de la versión moralista de la izquierda que por mucho tiempo mantuvo relegada a la juventud a un papel marginal y subordinado. ${ }^{11}$ Política no estuvo exenta de presentar este tipo

51 Hasta 1963, el lugar asignado en las páginas de la revista a la juventud fue más bien marginal, algo que cambió en buena medida por el movimiento estudiantil en Michoacán y Puebla. Por ejemplo, hasta 1963, la juventud mereció menciones que no estaban del todo mediadas por la línea editorial de la revista. Primero, en un artículo de Lázaro Cárdenas, donde señaló que "el pensamiento moderno abre perspectivas a las jóvenes generaciones incapaces de superar los vicios que imperan en la vida cívica, fortaleciendo su espíritu de responsabilidad” (“El MLN en la situación presente de México", Política, México, D. F., 15 de octubre de 1963, p. 23). A este artículo le antecedió el "Llamamiento al Segundo Congreso Latinoamericano de Juventudes" realizado en Chile, donde se exhortaba a la unidad como "imperativo que nos plantea la hora presente", necesaria para cumplir con la responsabilidad de participar en la "liberación de sus respectivos pueblos" (Política, México, D. F., mayo 15 de 1963 , p. 11). Luego, se los mencionó en un discurso de Fidel Castro reproducido en la revista, en el que se ensalzaba a las juventudes soviéticas por su vigor revolucionario, y se invocaba la necesidad de que en América Latina los "jóvenes con inquietudes por una sociedad sin clases, una sociedad justa" debían responder incluyendo en sus lecturas a Marx, Lenin y Engels, “los fundadores de la teoría, los constructores del primer Estado socialista por la hermosa oportunidad que abrieron a la humanidad" ("Palabras de Fidel Castro a los estudiantes de la URSS", Política, México, D. F., 1 de junio de 1963. p. 32). Un mes después, un reclamo similar se hizo en el "Llamamiento del Congreso Mundial de Mujeres" (Política, México, D. F., 1 de julio de 1963, p. 28.), donde la mujer como "madre de todos los niños del mundo" no podía permitir que hubiese "niños privados de alegría, hambrientos, analfabetos, explotados, desamparados, condenados a una muerte prematura". Un año después, en otra convocatoria, se refrendaría el llamado a la participación femenina en el asedio al régimen político mexicano, considerando "todas las inquietudes que se han despertado en la mujer", entre las que destacaba "la participación decidida y consciente, con todos sus deberes y derechos" (“Congreso Femenil de Unidad. Convocatoria del Comité Unificador Nacional de Mujeres”, Política, México, D. F., 1 de septiembre de 1964, p. 33). Para entonces, el tardío llamado a las mujeres para votar contra Gustavo Díaz Ordaz y el PRI sirvió como inspiración para coordinar esfuerzos con mayor anticipación, particularmente entre los miembros de los 
de posiciones que reducían a la juventud a prejuicios y anatemas, igual que la derecha y el régimen lo hacían con la izquierda. Asimismo, la progresiva irrupción de visiones alternativas al marxismo, que desde puntos de vista humanistas criticaban falencias en la principal fuente teórico-filosófica para la revolución, tuvo como respuesta de parte de colaboradores de la revista la condena a escritores como Herbert Marcuse y Erich Fromm, como muestra de una degradación en el pensamiento social crítico..$^{2} \mathrm{De}$ esta forma, Política empezó muy temprano a deslindarse de las corrientes intelectuales que mientras innovaban la principal vertiente en la teoría revolucionaria, establecieron un diálogo con la juventud que propició la expansión de los mecanismos de contención contra el establecimiento. Esto no niega un apoyo decidido de la publicación a las movilizaciones estudiantiles en Puebla, Michoacán y el Distrito Federal, pero sí constituyó un factor de incomprensión entre los sectores de izquierda que representaban, y las nuevas perspectivas que condensarían las movilizaciones predominantemente juveniles del paro del sector de la salud en 1965-1966, y el despertar del movimiento estudiantil de 1967-1968.

grupos de izquierda que, separados del MLN, intentaron mantener la inercia que tuvo el FEP en el preludio a las elecciones de 1964.

52 Mauro Torres, “Erich Fromm, maestro del ‘marxismo’ enajenado”, Política, México, D. F., 1 de julio de 1963. Aunque este texto no representa el pensamiento de la totalidad de la revista, sí fue de importancia pues, para la época, la mujer y la juventud empezaban a entrar en la discusión editorial y de colaboradores de la publicación, mientras mundialmente autores como Fromm y Marcuse impulsaban una revisión de la teoría marxista. El autor de esta columna, que apenas colaboraba esporádicamente, abordó los aportes de Erich Fromm desde la psicología como una desviación, y sin temor a que se lo tildara como agente del "estalinismo psicoanalítico", elaboró un juego de palabras y argumentos en los que sacralizaba al pensador alemán, mientras con anatemas sindicó de "dañina mística” y "seudomarxismo" los planteamientos del libro Marx y su concepto del hombre. Esta sería una significativa contribución en el debate, pues representaba la posición de los sectores más tradicionales y recalcitrantes de la izquierda mexicana de la década de 1960. De una parte, como señala Carlos Perzabal, Política en sus últimos años se acercó al Partido Comunista Mexicano, que clandestino y decadente, era inexistente en el panorama político y activista del país. De otra parte, el desprecio al nuevo humanismo y la Escuela de Frankfurt fue uno de los factores que marcaron revistas como ¿Por Qué? (1968-1974), y que alejaron por años a sectores de la juventud de izquierdas a visualizar el PCM como una fuerza revolucionaria. Cfr. Carlos Perzabal, Memorias...; Barry Carr, La izquierda...; José Agustín, Tragicomedia..., v. I. 
Los comentarios de Juan Duch antes mencionados, entre otros, dejan ver cómo la izquierda también formulaba términos moralistas que tendían a reproducir el modelo patriarcal centrado en el control paternalista sobre la juventud que el Estado promovía también sobre la sociedad, y sobre todo sobre mujeres y niños. Este factor impedía que el robustecimiento de la oposición al régimen político adicionara en su favor la fuerza innovadora juvenil, que entre 1966 y 1968 se volcaría sin que la izquierda tradicional pudiera comprender, contener o satisfacer las demandas juveniles, sobre todo en términos de las prácticas políticas que corroían su legitimidad y autoridad moral. En conclusión, la izquierda mexicana desplegaba a comienzos de los años 1960 muchas de las facetas moralistas de otros sectores políticos del país, y en cuya visión la juventud carecía de un papel político específico por fuera de su sombra condescendiente y paternal. Apenas fue en 1964 cuando en la revista se empezaron a tocar temas pedagógicos y de los valores insertos en los libros de texto escolares, sin que esto significara que los columnistas o la editorial bajara la guardia frente a la amenaza representada en la cultura popular. ${ }^{53}$ Sólo años después de la masacre

53 Entre otros ejemplos de la forma como se empezó a articular a la juventud en el debate político y la exaltación del compromiso como un aspecto heroico, vale la pena mencionar artículos de 1964 donde se asoció el accionar de “los jóvenes ‘desorientados' [que] se apandillan y asaltan, roban y destruyen” pero como resultado de “la 'orientación' más atractiva que se les ofrece es la riqueza mal habida" ansiosos por "ingresar al PRI y aspirar a los frutos del 'lopezavelarismo', el 'caballeroaburtismo' " (Alberto Domingo, "iLa impunidad es una conquista?”, Política, México, D. F., 1 de junio de 1964, p. 5). También, se habló de los soldados, denominados "Juanes", a quienes se les "impone la obligación ineludible de servir un año entero en milicias para imbuirles un espíritu castrense enanizado y antipedagógico [...] o laborar en quehaceres particulares para oficiales de alta graduación que los usan como sirvientes, choferes o jardineros". (Alberto Domingo, "Siempre con las botas puestas", Política, México, D. F., 1 de julio de 1964, p. 24). Finalmente, a los ojos de la izquierda reunida en Política, la crisis juvenil se sintetizaba en la resistencia del régimen a cambiar; esto se vio reflejado en el hecho de que existían "miles y miles de personas jóvenes [que] buscan un sitio desde el cual poder actuar políticamente”, por lo que el autor llamaba la atención sobre la necesidad de "dar atención al encuadramiento de nuevos militantes en los partidos, y más concretamente en los partidos que aspiran a representar a la clase obrera y que se empeñan en desarrollar su conciencia socialista". (Miguel Aroche Parra, "Política de partidos, no club de amigos”, Política, México, D. F., 1 de diciembre de 1964, p. 45). Este artículo hacía eco al interés del FEP por cautivar esa energía contestataria juvenil luego de los hechos de represión que experimentaron en Puebla estudiantes que apoyaban un movimiento de campesinos productores de leche. En un manifiesto publicado en la revista, decían al respecto que "el pueblo fue testigo de esa desproporcionada lucha, en la cual las fuerzas policiacas emplearon contra los jóvenes macanas, motocicletas, gases, pistolas, etcétera, mientras los estu- 
de Tlatelolco, esto se reflejó en la integración de una juventud cargada de "autoridad moral", y se hizo evidente en la ampliación de los grupos sociales a los que las publicaciones periódicas de la izquierda se dirigían. ${ }^{54} \mathrm{La}$ historia de esta experiencia juvenil en la política mexicana contemporánea está aún por ser analizada.

\section{El tejido moral: valores sociales y pedagogía para la educación juvenil}

Regresando a la problemática de los libros de texto, en 1964 Política se preguntaba en un editorial si acaso "gran parte de los libros de texto gratuitos inducen ese gusto por el historietismo de oropel patriotero, de panteón de héroes momificados definitivamente en el pasado". ${ }^{55}$ El temor estaba en que una educación orientada a ese tipo de reverencias limitaba el

diantes pelearon con la inquietud revolucionaria de justicia que caracteriza a la juventud mexicana". ("Los acontecimientos de Puebla. Manifiesto del Frente Electoral del Pueblo", Política, México, D. F., 1 de noviembre de 1964, p. 47).

54 A pesar de las movilizaciones estudiantiles en Puebla y Michoacán, los colaboradores de la revista mantuvieron a partir de 1963 una posición ambigua frente a la activación de la juventud en la vida política nacional. De una parte, Ermilo Abreu señaló que la movilización de Puebla fue ejemplar para la izquierda, pues se trataba de muchachos que, "arriesgando su libertad y su vida, pusieron su juventud, su energía y su conciencia cívica al servicio de una causa digna de la sombra de Aquiles Serdán [...], no salieron a la calle para defender intereses de su clase", razón por la que su incursión demostraba la existencia de "una fuerza moral que dio ánimo al pueblo rebelde para proseguir una lucha legítima” (Ermilo Abreu, “Elogio de la juventud poblana”, Política, México, D. F., 15 de noviembre de 1964, p. 21). De otra parte, en torno a la represión de una protesta contra la guerra en Vietnam, que tuvo lugar frente a la Embajada de los Estados Unidos en el Distrito Federal, Alberto Domingo señaló que la conciencia juvenil ahondó en el reconocimiento del irrespeto de la soberanía nacional en el que incurría el imperialismo. Un proceso importante para “los muchachos, que aunque su edad no les permita aún el reconocimiento sereno de los sabios de gabinete, ya conocen y aceptan sus deberes de solidaridad humana con los pobres y los oprimidos del mundo". (Alberto Domingo, “Un menguado triunfo policiaco”, Política, México, D. F., 15 de abril de 1965). Se trata de exaltaciones del heroísmo juvenil y su compromiso político, sólo que el último ejemplo estaba afectado por la visión condescendiente propia del paternalismo imperante en la izquierda mexicana de los años 1960. Ambos casos expresan la pluralidad de percepciones sobre la juventud que concurrieron en la revista, un fenómeno que se reflejaría más adelante en las dificultades de la izquierda tradicional para articularse o siquiera comprender la naturaleza del movimiento de 1966-1968.

55 Editorial, “¿Educación para liberar o para encadenar al semialfabetismo?”, Política, México, D. F., 1 de septiembre de 1964, p. 4. 
fortalecimiento de un umbral crítico juvenil que llevara a confrontar la desviación revolucionaria. Desde esta perspectiva, en 1964 el cuestionamiento moral a la educación y la cultura popular no caía sólo en la responsabilidad que podían tener los organismos públicos y privados que controlaban y promovían lo que se transmitía por los medios de comunicación, sino que involucraba temas de fondo como lo es el diseño de un modelo político-filosófico de enseñanza. El antagonismo de fondo entre seguidores y críticos de una educación privada expansiva empezaba a volcarse hacia un intercambio de opiniones e insultos basado en los valores que en las aulas de clase eran transmitidos. La capacidad de una visión moral del mundo para constituirse en el sustento de un sistema de creencias depende de la aceptación que los individuos y el colectivo hacen de valores que le sirven de rasgos de identidad, y a través de los cuales se establecen normas de conducta e interacción social..$^{6}$

$\mathrm{Al}$ respecto, la revista Política no estaba separada de la órbita ética y política que guiaba el debate nacional, y más bien constituía el barómetro para medir la crisis educativa del país en el contexto de las protestas de padres de familia por el tema de los textos escolares. Así lo expresó Tomás Cuervo, reconocido luchador social del SNTE:

El orden moral no es concebible mientras prevalezca la acumulación de capitales en manos de una minoría privilegiada, ni los capitalistas están autorizados a reclamar moralidad, en virtud de que son ellos los que deforman a la sociedad estableciendo desigualdades económicas inhumanas. La moral no se explica como conjunto de reglas abstractas al margen de la realidad sino como el encauzamiento de nuestras acciones con apego a la justicia a fin de que el bienestar individual y colectivo se cimiente en la distribución equitativa de la riqueza. ${ }^{57}$

Es interesante cómo la relación inextricable entre valores sociales y moral en el debate educativo se asociaba con aspectos jurídicos. La explicación más evidente reposa en el impulso de la burguesía nacional a la 
educación privada y católica, y las argumentaciones basadas en los derechos salvaguardados en la Constitución sobre la libertad de cultos.

El aura jurídica que teñía el debate no se limitaba a ese comentario. En un artículo anterior, Tomás Cuervo denunció la estrategia de sectores conservadores en Nuevo León promoviendo manifestaciones masivas en contra de la educación pública y los libros de texto, en las que propagaban un discurso fundamentado en "la declaración de los derechos humanos" en la que se asienta que "la educación tiene por objeto el desarrollo de la personalidad humana y el fortalecimiento del respeto por los derechos humanos y las libertades fundamentales". Para el columnista, el cinismo de las asociaciones de padres de familia estaba en que promovían la supeditación de las directrices legales plasmadas en la Constitución por las "creencias personales”. Ese asalto a la legalidad constitucional de los libros de texto legaba a una de las estructuras más importantes para el entramado simbólico de la Revolución y el régimen político -la familia- la obligación de salvaguardar el derecho de los infantes a adquirir los valores adecuados para su formación como ciudadano. Tomás Cuervo además señaló cómo los políticos locales se apresuraron a dar un guiño aprobatorio a las marchas porque como servidores públicos "comparten el derecho natural de los hombres libres del mundo para inculcar en nuestras ciudades principios morales, culturales, históricos y religiosos que recibimos a través de nuestros padres". ${ }^{8} \mathrm{El}$ tema de la moral estaba intrincadamente alineado con los postulados jurídicos del debate sobre la educación y los libros de texto.

En términos de las condiciones sociales de la educación, los detractores de los libros de texto también estaban respaldados por la función que desempeñaba el ideal de la "familia revolucionaria" entre los pilares simbólicos de la unidad nacional. Sería una realidad económica -la efectiva presión de la iniciativa privada contra el gobierno- la que facilitaría los cambios progresivos al sistema educativo en las décadas que siguieron al debate. La pregunta que aquí surge es sobre el papel que desempeñaban

58 Tomás Cuervo, “La educación y las fuerzas reaccionarias”, Política, México, D. F., 1 de marzo de 1962, p. 11. En la nota editorial de Política del 15 de febrero de 1962 se hizo también referencia a las marchas de padres de familia. Allí se menciona un discurso realizado en plaza pública, donde calificaban que "los sistemas que pretenden implantar son francamente comunizantes”, a lo que la revista dirigió su análisis al esclarecimiento del derecho del gobierno de dar a la enseñanza pública la orientación señalada por la Constitución. 
los libros de texto en la formulación de unos parámetros morales y la promoción de valores, y la posición que Política expresó como vocal de la izquierda mexicana. El examen de esta pregunta debe arrojar luz sobre los horizontes morales que suscribían el periodismo de la izquierda, los padres de familia y el régimen político.

En primer lugar, para el régimen era beneficioso mantener una línea de continuidad tras décadas de nacionalismo. Según su principal representante, los libros de texto tenían "un valor pedagógico e inspiración patriótica [que] sólo puede desconocer la pasión sectaria". ${ }^{59}$ Continuaba en su discurso el presidente López Mateos, dirigiéndose a un grupo de profesores, administradores de la educación y padres de familia en Guadalajara durante la celebración del Día del Maestro, señalando que al lado de los libros de texto "seguiremos buscando los medios más idóneos para superarlos, educando con ellos a la niñez mexicana en el amor a la patria, en el ejemplo de nuestros héroes, en el apego a nuestras tradiciones, en la devoción a la familia y en la fraternidad hacia los pueblos del mundo". Los pilares de la estabilidad de la nación se sostenían aun en esos valores en crisis que, proyectados en las escuelas y reproducidos en la efectividad creciente de la cobertura escolar promovida por la SEP, mantenían al Estado con la seguridad de tener un firme control sobre la educación que recibirían niños y jóvenes. Si la lealtad juvenil al régimen estaba garantizada, no habría temor a que las prácticas políticas fueran afectadas por cuestionamientos, así fueran de orden moral. Política aplaudió esta respuesta del presidente a los "reaccionarios sedicientes padres de familia", y en varios números en los años sucesivos presentó las cifras exitosas del plan de expansión educativa. ${ }^{60}$ La aparente luna de miel entre Adolfo López Mateos y algunos colaboradores de Política no debe llevar a engaños, pues la relación de la izquierda en general y de la revista en particular estuvo

59 “Panorama Nacional, Torres Bodet vs. López Mateos”, Política, México, D. F., 1 de junio de 1962, p. 30.

60 “Un balance positivo: el de educación”, Política, México, D. F., 15 de noviembre de 1964, p. 8. El director Manuel Marcué Pardiñas tenía cierta cercanía con el presidente López Mateos que superaba el interés por los autos lujosos y la velocidad. Esto marcó los vaivenes editoriales de la revista hasta el final de su sexenio, algo que se manifestaba en temas como el de la educación y las reformas electoral y política; la amistad se resecó con la selección del presidente de Gustavo Díaz Ordaz como el elegido candidato del partido de gobierno. Cfr. Carlos Perzabal Marcué, Memorias... 
siempre matizada por otros temas candentes que la separaban del PRI, como el de la represión, la manipulación de la prensa, los recortes de suministros para los órganos periodísticos de oposición, el tema de los presos políticos, la ambigüedad diplomática ante Cuba o la perpetuación de prácticas como las del futurismo y el "tapadismo". ${ }^{61}$

En segundo lugar, la crítica de la izquierda, que se sirvió de Política como válvula de escape, hacía burlas del carácter folclórico de los valores nacionalistas que constituían verdaderos aderezos pedagógicos con los que se enriquecían y domesticaban, con el lenguaje autóctono escolar, las versiones oficiales de la historia mexicana. Se ha escrito con amplitud sobre el papel de la enseñanza de la historia, y su emparejamiento con pautas de civismo y los anclajes místicos del nacionalismo. ${ }^{62}$ Sin embargo, estos trabajos no han confrontado el problema de la influencia de los valores enseñados en las escuelas y la forma como articularon la veneración al sistema político. Es necesario considerar la educación mexicana como una herramienta funcional para establecer una doctrina nacional, como un sistema de creencia secular o una religión civil. ${ }^{63} \mathrm{El}$ arsenal simbólico y las narrativas épicas con las que floreció el nacionalismo mexicano dan buena cuenta de ello. ${ }^{64}$ Esto se hacía notar en Política. Por ejemplo, Jorge Carrión escribió una crítica mordaz respecto a la participación de Jaime Torres

61 Vale la pena señalar que el director Manuel Marcué Pardiñas profesaba un profundo respeto y admiración por Vicente Lombardo Toledano, un factor que determinó cierta inconformidad entre sectores del régimen que veían allí y en el apoyo a la Revolución cubana una cimiente radical nociva para el PRI y la estabilidad del sistema político mexicano. Colaboradores como Jorge Carrión tenían similares inclinaciones, lo que causaba sospechas respecto a lo novedoso de la propuesta periodística dentro de la izquierda, así como tempranas fricciones con colaboradores y otros medios escritos. Cfr. Carlos Perzabal Marcué, Memorias...

62 Cfr. Anne Rubenstein, op. cit.; Mary Vaughan et al., The eagle and the virgin...; Mary Vaughan, La política cultural...; Rafael Segovia, La politización del niño mexicano, México, El Colegio de México, 1977.

63 Cfr. Catherine Bell, op. cit.; William Beezley et al., op. cit. En México, como en toda Latinoamérica, uno de los factores que más ha limitado el despliegue del concepto de religión civil es la profunda correlación entre el poder político y el poder religioso del catolicismo, incluso después de la Revolución mexicana y sus agudos momentos de anticlericalismo. Uno de los inconvenientes de esta tendencia es que limita las posibilidades de escrutar los marcos morales imperantes, porque se asume que sólo hay uno legítimo cuya extensión secular esta cristalizada en el Estado y sus instituciones.

64 Cfr. Eric Van Young, "Epilogue”, en William H. Beezley et al., Rituals... 
Bodet en el mismo acto en Guadalajara, porque para el periodista su discurso "fue un adobo de filosofía, ética del bien y del mal, e historia de tan patriotero colorido que el águila del traje lentejueleado quedó penosamente acostada". El artículo demostraba una preocupación por la moral intrínseca en la tarea educativa, que el alto funcionario decidió evitar en su discurso, pues optó por combinar los adornos folclóricos con minucias administrativas que servían para evadir el tema de fondo y más bien subsanar cualquier duda sobre su ejercicio en la función pública. Sin embargo, la exaltación nacionalista y los destellos de eficacia burocrática no podían ocultar "el riesgo que para la educación del país entraña la violación diaria y consentida por la SEP del artículo 3o. constitucional" frente a la abierta negociación del derecho a la educación en la que actuaba "la legión del fanatismo reaccionario [...] la triple alianza del clero, la burguesía regiomontana y el imperialismo yanqui -kukluxklanes del libro de texto- que combate no sólo la educación sino la independencia nacional”.

Para Jorge Carrión, el problema era más bien de procedimiento, pues a lo largo de los debates no se enfrentaba el problema de fondo que era la actualización de los valores referenciales transmitidos en la educación primaria y secundaria. No se incorporaba en las aulas escolares el discernimiento de los motivos que inspiraron la Revolución mexicana, y mucho menos se mencionaba en los libros de texto su cambio de dirección en detrimento de las mayorías más necesitadas. En su lugar, se resolvía la crisis activando los mecanismos tradicionales del PRI para mantener sin deterioros su legitimidad en el poder; es decir, eliminando la presión más inmediata -por ejemplo, las dudas en la opinión pública sobre el presidente y su secretario- para comodidad del gobierno, cediendo ante la iniciativa privada durante una crisis de confianza respecto al presidente Adolfo López Mateos por sus devaneos protectores de Cuba y las definiciones de su gobierno como de "izquierda atinada". Tampoco se revisaba el impacto de solucionar las carencias educativas por la vía privada, ya que "en aras de tal grandeza, sin rencores ni memoria, don Jaime olvidó en sus citas de mexicanidad de lentejuela, de batallas de 5 de mayo y alaridos patrioteros, fechas que nada dicen ni nada significan [que] la derecha arrojará la presa fofa de sus alimentos excedentes y aflojará un poco la cadena de la alianza para el progreso”. Lo que el periodista veía como un aspecto crítico de "la frontera moral que pasa por la escuela" representaba en últi- 
mas un ultraje a los símbolos mismos del nacionalismo. Este punto lo expresó en unas líneas llenas de sarcasmo, como acto de salvación ante el sacrilegio que se cometía con la infancia mexicana: "a fuerza de planchar el traje, por obra del uso reiterado y estéril, el águila falsa del patriotismo a lo china poblana acabó por rendir sus alas ante las muy poderosas del dólar norteamericano". ${ }^{65}$ Sin duda el temor por la crisis de valores y su impacto en la juventud no limitaba la audacia y la jocosidad de los comentarios del periodista respecto al régimen.

Finalmente, un escrutinio de las entrañas de la política educativa del país también se publicó en las páginas de la revista. Hernán Escalante, maestro de matemáticas y militante comunista que había participado en la formación de la CTM y que apoyó la escisión de la IX sección del SNTE a través de su acción y liderazgo con el MRM, era una voz preclara para denunciar los problemas de fondo en la orientación, ya no burocrática o textual, sino de los postulados filosóficos que sostenían el proyecto educativo nacional para niños y jóvenes. Escalante apuntó sus dardos hacia la necesaria revisión de los marcos pedagógicos usados en su confección, y cuestionó su idoneidad tanto para la época mundial, como para las necesidades del país. La pedagogía de John Dewey era la médula filosófica de la educación pública mexicana, producto de la asociación -juzgada por Escalante como apresurada y equívoca- de su carácter liberal o de izquierda para el contexto norteamericano, en tanto su ideal en las aulas de clase era "erradicar la explotación de una clase por otra”. ${ }^{66}$ Sin embargo, para Escalante esto era lesivo de los intereses nacionales, si por ellos se entiende la continuación de la Revolución mexicana como un esfuerzo por cerrar la brecha entre ricos y pobres, vía la exaltación de los valores democráticos y de justicia social. John Dewey promovía limar asperezas interclasistas en el entorno escolar a través de una limitación de las manifestaciones explícitas de sus antagonismos. El modelo a seguir era la promoción de "la transmisión de conocimientos prácticos para la autorrealización personal”, a través de un ejercicio pedagógico interactivo que estimulaba a la niñez buscando

65 Jorge Carrión, “La pedagogía a lo china poblana”, Política, México, D. F., 15 de mayo de 1962, p. 17.

66 Hernán Escalante, “Los nuevos programas de enseñanza privada”, Política, México, D. F., 1 de octubre de 1962, p. 16. 
sus intereses individuales. Valores como la tolerancia, el optimismo, la cooperación, la comprensión y el tacto en las relaciones interpersonales, "las cualidades del business-man", estimulaban la "adaptación del niño al medio social" a la vez que limitaban el impacto de nociones anticapitalistas en una democracia liberal. Escalante denunciaba cómo los niños desde 5 o. y 6o. año en adelante "deben realizar estas 'actividades creadoras': juegos y pasatiempos... Charadas y crucigramas, canicas, baleros y papalotes", todos ejemplos de la intensa búsqueda por equipararse a "los arquetipos norteamericanos de desintelectualización de la escuela". ${ }^{67}$

Si bien los llamados de este maestro fueron desestimados, pues la estrategia pedagógica de John Dewey no representaba una amenaza concreta para los intereses de las elites que reclamaban una apertura educativa que incluyera la promoción de valores propios del credo católico, la izquierda mantuvo activo este debate a lo largo de las reuniones del MRM, que Política de buen agrado siguió en sus páginas hasta 1967. El interés no era otro que condensar en la educación pública un legado de valores y principios morales que, articulados con el conocimiento de la historia nacional y la realidad concreta mexicana, estimularía en la juventud una sensibilidad ante la necesidad de cambiar el rumbo de la revolución vilipendiada y desorientada del horizonte al que apuntó el sacrificio de los padres de la patria. Sin embargo, el hecho de que Política plasmara en sus páginas las concepciones de periodistas y políticos respecto a la juventud no significaba que se despojara de la perspectiva paternalista y condescendiente, y mucho menos que abandonara el tono canónico de otro moralismo impuesto sobre niños y jóvenes. Esto evidencia el carácter autoritario de la política en México que la izquierda, por más que intentara volcarse en contra del régimen, había heredado como un tigre hereda algunas de las marcas de sus ancestros. Justamente esta naturaleza ambigua en el carácter del liderazgo de la izquierda política mexicana requirió que en sus filas se formalizaran anclajes que dieran forma a un nuevo perfil subjetivo de revolucionario, del cual emanarían nuevos elementos para que su autoridad moral se desligara de las ataduras creadas por el régimen de la Revolución y el PRI, durante décadas de gobierno autoritario en el país. El momento en el que se desplegaría esa mística de la izquierda coincidió con el desper- 
tar juvenil a la vida política, pero para entonces Política ya había salido de circulación merced a las presiones del gobierno y a las contradicciones inherentes de los motores del proyecto periodístico que tanto inspiró a la oposición mexicana durante siete años. Los jóvenes, juzgados por amplios sectores de la adulta y madura izquierda como moralmente desorientados y carentes de una mano diligente que les guiara en su extravío rebelde, tendrían en el movimiento de 1968 la posibilidad de constatar la falta de consecuencia política y moral de sus líderes tradicionales, quienes a la postre, convertirían las crujías y celdas en la plataforma para perpetuar la legitimidad de su liderazgo, pese a haberle fallado una vez más a México en uno de sus momentos cruciales.

\section{Conclusión}

En 1965, las páginas de Política mostraban cambios significativos en su plantilla, el tono de sus columnas y editoriales, y la manera como sus colaboradores se inmiscuían en el activismo contestatario de la época. La guerra en Vietnam, la ocupación norteamericana a la República Dominicana y su creciente presión sobre la frontera norte del país fueron temas objeto de escrutinio por parte de los periodistas, además de problemas internos como el paro de los trabajadores de la salud y una incómoda presión del gobierno sobre las universidades públicas. A estos cambios en la textura de Política, se le debe sumar un interés por las experiencias insurgentes de Argelia y el florecimiento de las guerrillas en países de América Latina como Colombia, Guatemala, Perú y Venezuela. Algunas de las columnas y editoriales más viscerales vinieron con la violenta transición brasilera que expulsó a João Goulart del poder en abril de 1964, que sirvió para incluir entre la fauna de la "familia revolucionaria" al gorila como una alegoría de la represión militar. La revista desde 1963 había adoptado en sus páginas - una de las excusas para la salida de Carlos Fuentes y compañía en 1964- la sección "Documentos de la Quincena”, que sirvió para reproducir los ecos ideológicos de toda la izquierda internacional, en especial de Cuba, la URSS y Argelia, sumados a exámenes críticos de la formación del partido oficial que en entregas seriadas refrescaban el fervor opositor en sus lectores. La redacción de Política adoptaba así un talante pedagógico y contestatario de cara a los problemas de México, orientado a estimu- 
lar la formación de sus lectores y enmendar las divisiones de la izquierda avivadas luego de la erosión sufrida por el MLN en 1964-1965.

Mientras su línea editorial se radicalizaba, el perfil del periodista heroico iba tomando consistencia. ${ }^{68}$ Surgió un especial interés por el examen del marxismo en su versión humanista, de la mano de Jean-Paul Sartre y Eric Fromm, que vino a dar carta de ciudadanía en el imaginario político de la izquierda al periodista e intelectual heroico que en México, como en Francia y Norteamérica, tenía en las universidades un nicho propicio para su vocería crítica contra el imperialismo y las fallas de los sistemas democráticos en todo el planeta. Esa reverencia al periodismo intrépido, aquel que marchaba a contracorriente de los regímenes y que se embelesaba en las noticias sobre la ordalía por la que tuvo que pasar Régis Debray en Bolivia al ser capturado mientras seguía los pasos trazados por el heroico Ernesto “el Che" Guevara, germinaba ya en 1962, cuando Política rindió un sentido homenaje al académico y activista C. Wright Mills, y exaltaba el movimiento por los derechos civiles en los Estados Unidos, este último quizá el tema que abrió un espacio en sus páginas a la juventud como

68 La línea editorial de Política había adoptado una clara beligerancia después del asesinato de Rubén Jaramillo en mayo de 1962, y de sus páginas salieron agudas críticas al esquema represivo del gobierno de Adolfo López Mateos, así como la inusitada autonomía de los organismos de seguridad que empezaban a transgredir la tradicional dependencia frente al ejecutivo. Un año después, la revista mantenía sus ácidos comentarios y señalamientos respecto a la represión sindical, como lo deja ver un artículo donde denunciaba la participación oficial en la muerte de Román Guerra, Raúl Todd -ambos destacados luchadores sindicales-y Rubén Jaramillo en la brutal masacre de Xochicalco- (cfr. "A los procuradores de los estados, reunidos en el Segundo Congreso Nacional de Procuradores”, Política, México, D. F., 15 de mayo de 1963, p. 13), mientras exaltaba el heroísmo de los luchadores sociales y la creciente amenaza sobre los periodistas de oposición. La forma como el asesinato de Rubén Jaramillo despertó las alarmas del periodismo de izquierda bien daría para escribir investigaciones completas, que desafortunadamente en este artículo se tocan apenas tangencialmente. Valga sin embargo aclarar que la beligerancia frente al tema de autores como Carlos Fuentes, Fernando Benítez y otros escritores sirvió para que se enalteciera la lucha insurgente y el activismo en el ámbito rural, que aunque un aspecto central y necesario en la formación de una esfera pública, sirvió para destacar intelectuales que con el tiempo se acomodarían bajo el manto protector del régimen político mexicano, incluso después de la masacre de Tlatelolco. 
actor político significativo. ${ }^{69}$ Política fue sensible a esas orientaciones de la izquierda internacional y al color local de la protesta social, pero carecía de la energía y la beligerancia del movimiento estudiantil que caracterizó la protesta juvenil a lo largo de la década.

Ninguno de estos cambios en Política fue gratuito, pues se emparentaban con el apoyo a las luchas de liberación y descolonización, además de la fascinación con la figura mística de Camilo Torres en el ELN colombiano. Practicante del periodismo, la lucha social y la docencia, el cura guerrillero constituyó uno de los anclajes de la nueva mística revolucionaria de la que Política se hizo pionera y eje informativo. Su muerte en 1966 fue registrada con pesar en sus páginas, a lo que se respondió con exaltaciones por el heroico sacrificio en las llamas purificantes de la revolución social. Del mismo modo, Régis Debray se sumaría a la lista de los arquetipos de la acción y el compromiso revolucionario, como escritor, periodista, docente e intelectual activo en la lucha revolucionaria en Bolivia; fue una gesta que lo arrastró a la cárcel, lugar que le terminó de otorgar la autoridad moral que los militantes de izquierda le buscaban arrebatar a los regímenes políticos que dominaban la mística revolucionaria. ${ }^{70}$

69 La muerte del afamado sociólogo se ajustó al debate en torno al papel de los intelectuales en Política. Cfr. editorial “Muere Mills”, Política, México, D. F., 1 de abril de 1962, p. 2a. de forros. Sobre los antecedentes inmediatos en la revista, cfr. "¿Hacia un encuentro mundial de intelectuales?”, Política, México, D. F., 1 de octubre de 1962, p. 45. Años después, en medio de la crisis causada por la censura, los ajustes de la plantilla del Fondo de Cultura Económica y el proceso judicial que desencadenó el libro de Oscar Lewis Los hijos de Sánchez, se promovió en la revista una semblanza del intelectual como héroe y figura necesaria en el cambio social del país que incluyó una encuesta a lo más destacado de los escritores del país. Cfr. Jorge Carrión, “Los hijos de Sánchez de las reuniones interparlamentarias”, Política, México, D. F., 15 de febrero de 1965, p. 13. La Nación “Los hijos de Sánchez”, Política, México, D. F., 1 de marzo de 1965, p. 14-15. De alguna forma, el heroísmo periodístico estaba a mitad de camino entre el compromiso político en su máxima expresión al estilo guevarista, y la tibia respuesta posible en un periodismo de izquierda que, si bien no estaba en flagrante colusión con el régimen, se mantenía muy a la expectativa de sus movimientos en particular para inclusiones partidistas por la vía de alianzas. Cfr. Barry Carr, La izquierda...

70 Otro ejemplo temprano en ese despertar del periodismo heroico como marco de acción en la revista fue la ejecución del periodista español Julián Grimau por parte del régimen franquista. En línea con la política exterior mexicana de mantener mínima relación diplomática con España, este hecho servía de ejemplo en la izquierda para mostrarle al partido de gobierno en México cómo en sus cárceles algo similar sucedía, sin que la contradicción le 
La mayoría de estos arquetipos de acción política y reflexión intelectual se asocian con la idea del hombre nuevo. Su estudio es necesario a la luz del difícil tránsito de jóvenes y mujeres a la escena pública y política, pero deben existir antecedentes para sumergirse en lo que esa noción realmente significó en la política de los años 1960 en el país. Esta investigación se orienta de forma general a la comprensión de ese fenómeno, anteponiendo la realidad concreta mexicana a cualquier divagación teórica sobre subjetividad y masculinidad que carezca de asidero empírico o un antecedente analítico que la avale.

En este artículo se han introducido algunas de las facetas más destacadas de los debates propios del periodismo de la izquierda entre 1960 y 1967, como una contribución inicial al examen de los perfiles de moralidad y heroísmo que surgieron en los años 1960. Estos elementos de análisis constituyen una muestra de los rasgos de subjetividad política más interesantes a que dio lugar una década compleja de la historia contemporánea mexicana. Internamente, Política se había repuesto de la partida de cinco de sus colaboradores más reconocidos, hecho que favoreció el tallado de los contornos del periodismo heroico. En México, el oficio de periodista así como la docencia y reflexión intelectual constituyeron una tarea titánica propicia sólo para aquellos dotados de resistencia y arrojo, puesto que el compromiso iba hasta donde durara la resistencia personal a los medios represivos usados por el poder del régimen de la ya descompuesta Revolución mexicana. Los temas examinados fueron importantes en la configuración de un ideal de subjetividad revolucionaria, que veía críticamente el sistema educativo, el discurso nacionalista sobre la Revolución mexicana, y que tenía en la juventud la esperanza de formar los hombres nuevos, encargados de mantener viva la antorcha de la justicia social.

De allí en adelante, la redacción de la revista concentró buena parte de su energía en completar los rasgos del arquetipo heroico de compromiso con el periodismo, la investigación social y la docencia. Ya fuera a través del seguimiento de las opiniones de intelectuales mexicanos acerca del compromiso con la lucha social, desencadenado luego de un discurso de

causara el más mínimo sonrojo a sus dirigentes. Cfr. Ermilo Abreu, “Franco, apóstol del crimen", Política, México, D. F., 1 de mayo de 1963, p. 29. 
Jean-Paul Sartre en la URSS en 1963, o como resultado de la dirección que adoptó la Revolución Cubana y el regreso de Ernesto "el Che" Guevara a las lides insurgentes en Bolivia y el Congo, Política se involucró de llenó en los debates propios de los movimientos de liberación nacional que tenían en la construcción de un ideal del hombre nuevo la oportunidad de tonificar el impulso revolucionario en la dirección que seguían las fuerzas sociales más importantes del momento.

Los horrores de la experiencia heroica del periodismo los vivirían Víctor Rico Galán y Manuel Marcué Pardiñas en la cárcel. Paradójicamente, desde 1961 ellos mismos con sus escritos exigían la liberación de los presos políticos mientras elevaban a Filomeno Mata y David Alfaro Siqueiros como héroes insignia del compromiso revolucionario. Igualmente, Demetrio Vallejo y Valentín Campa, Encarnación Pérez, Alberto Lumbreras entre otros que habían inspirado una generación de rebeldes durante la insurgencia obrera de 1958-1959, ejercitaron la pluma periodística desde sus respectivos centros de reclusión. Con la reclusión de intelectuales y periodistas, el régimen de la Revolución animó el fuego que galvanizaría el perfil heroico de quienes denunciaron su decadencia y arbitrariedades. Sin embargo, mientras atizaba el fuego del purgatorio al que condenó a sus opositores en celdas llenas de presos políticos, la llama de su legitimidad en el poder se extinguía. Estas fueron las vivencias que servirían de enseñanza para una generación de jóvenes cuyo ánimo e interés en la definición del rumbo de su país tuvo en Tlatelolco su página más trágica.

\section{Fuentes}

Política: Quince días de México y el Mundo (1960-1967).

La Prensa (1958-1962).

Caridad y Patriotismo. Órgano de la Cruz Roja de Cuautla (1953-1963).

Brecha: por la Superación de México (1962-1965).

\section{Bibliografía}

Adler de Lomnitz, Larissa, Cómo sobreviven los marginados, México, Siglo Veintiuno Editores, 1985. 
Agustín, José, Tragicomedia mexicana, 2 v., México, Planeta, 1992.

Beezley, William H., et al., Rituals of rule, rituals of resistance: public celebrations and popular culture in Mexico, Wilmington, SR Books, 1994. Bell, Catherine, ritual theory, ritual practice, Oxford, Oxford University Press, 2009.

Camp, Roderic, Líderes políticos de México, su educación y reclutamiento, México, Fondo de Cultura Económica, 1983.

Carr, Barry, La izquierda mexicana a través del siglo XX, México, Era, 1996.

Cohen, Deborah, y Lessie Jo Frazier, "México 68: hacia una definición del espacio del movimiento. La masculinidad heroica en la cárcel y las 'mujeres' en las calles”, Estudios Sociológicos, v. 22, n. 3, 2004, p. 591-623.

, “'No sólo cocinábamos...': historia inédita de la otra mitad del 68”, en Ilán Semo, La transicion interrumpida: México 1968-1988, México, Universidad Iberoamericana/Nueva Imagen, 1993.

Cosío Villegas, Daniel, El sistema político mexicano: las posibilidades de cambio, México, Joaquín Mortiz, 1976. , La crisis de México, México, Clío, 1997.

Gilbert, Joseph, et al., Fragments of a golden age: the politics of culture in Mexico since 1940, Durham, Duke University Press, 2001.

Lewis, Oscar, Los hijos de Sánchez, México, Grijalbo, 1982.

López Cabrera, Patricia, Una inquietud de amanecer: literatura y política en México, 1962-1987, México, Universidad Nacional Autónoma de México/Plaza y Valdés, 2006.

O'Malley, Illene, Hero cults and the institutionalization of the Mexican State, 1920-1940, Nueva York, Greenwood Press, 1986.

Perzabal Marcué, Carlos, De las memorias de Manuel Marcué Pardiñas, México, Rino, 1997.

Reynaga Mejía, Juan Rafael, La Revolución cubana a través de la revista Política en México: construcción imaginaria de un discurso para América Latina, tesis de licenciatura en Estudios Latinoamericanos, México, Universidad Nacional Autónoma de México, 2005.

Rivera Castro, José, "Balance histórico de la revista Problemas Agrícolas e Industriales de México", Tiempo y Escritura, Universidad Autónoma Metropolitana, 1 (2004) [documento en línea en formato html]: 
http://www.azc.uam.mx/publicaciones/tye/tye16/art_hist_o1.html, consultado 31 agosto de 2012.

Rubenstein, Anne, Bad language, naked ladies and other threads to the nation: a political history of comic books in Mexico, Durham, Duke University Press, 1998.

Segovia, Rafael, La politización del niño mexicano, México, El Colegio de México, 1977.

Torres Septién, Valentina, "Estado contra Iglesia/Iglesia contra Estado. Los libros de texto gratuitos: ¿un caso de autoritarismo gubernamental 1959-1962?", Historia y Grafía, Mexico, D.F., Universidad Iberoamericana, 2011, p. 19-37.

, La educación privada en México: 1903-1976, México, El Colegio de México/Universidad Iberoamericana, 1997.

Vaughan, Mary, Estado, clases sociales y educación en México, México, Fondo de Cultura Económica, 1982.

_L La política cultural en la Revolución: maestros, campesinos y escuelas en México, 1930-1940, México, Fondo de Cultura Económica, 2001.

Vaughan, Mary, et al., The eagle and the virgin: nation and cultural revolution in Mexico, 1920-1940, Durham, Duke University Press, 2006.

Weeks, Charles A., The Juárez myth in Mexico, Tuscaloosa, University of Alabama Press, 1987.

Zolov, Eric, Rebeldes con causa: la contracultura mexicana y la crisis del Estado patriarcal, México, Norma, 2002. 